\title{
Exploring the Effects of Green Infrastructure Placement on Neighborhood-Level Flooding via Spatially Explicit Simulations
}

\author{
Moira ZELLNER \\ University of Illinois at Chicago \\ 412 S. Peoria St. (MC 348) \\ Chicago, IL 60607 \\ +1-312-996-2149 \\ mzellner@uic.edu \\ Dean MASSEY \\ University of Illinois at Chicago \\ dmasse2@uic.edu \\ Emily MINOR \\ University of Illinois at Chicago \\ eminor@uic.edu \\ Miquel GONZALEZ-MELER \\ University of Illinois at Chicago \\ mmeler@uic.edu
}




\section{Introduction}

Stormwater management is a challenge exacerbated by urban and agricultural

3 development at all scales. As the percent of impermeable cover within a watershed increases,

4 stormwater volume, peak flow, and concentration of non-point source pollutants increase

5 (Athayde et al., 1983). In urban areas, traditional gutter and storm sewer systems are often

6 inadequate for reducing the quantity of stormwater runoff or decreasing pollutant loads (Hood,

7 Clausen, \& Warner, 2007). In agricultural or rural areas, drainage systems quickly channel large

8 volumes of water, sediment, and dissolved pollutants to waterways (Nelson \& Booth, 2002). In

9 both urban and rural settings, inadequate stormwater management can lead to flooding, erosion,

10 and impaired aquatic habitats (Finkenbine, Atwater, \& Mavinic, 2000). Additionally, global

11 climate change is expected to cause more heterogeneity in the frequency and/or intensity of

12 storms (Bonebrake \& Mastrandrea, 2010), further stressing existing stormwater systems. The

13 climate models developed by the International Panel on Climate Change (IPCC) predict an

14 increase in average annual precipitation for the Midwestern United States of up to 20\% by the

15 end of this century. For example, in the Chicago metropolitan area, Illinois, this could range

16 from 5 to 9 additional inches of rain per year, and storms producing more than 2.5 inches of rain

17 in 24 hours are expected to more than double in frequency (Hayhoe \& Wuebbles, 2008).

Best management practices (BMPs), which can include green infrastructure, are typically

19 recommended by planning agencies to control discharge rates in developed and developing areas

20 (Jaffe et al., 2010). In the context of stormwater management, green infrastructure is designed to

21 minimize the generation of urban stormwater runoff and associated pollution by using and

22 mimicking natural systems to collect, treat, and infiltrate rain where it falls (Montalto et al.,

23 2007), i.e., at the site level. Examples of green infrastructure for stormwater management include 
24 swales, bioinfiltration devices, green roofs, constructed wetlands, or permeable pavement. Green

25 infrastructure can facilitate stormwater management in several ways and at different scales.

26 Runoff volume can be reduced through infiltration, evaporation, and evapotranspiration by plants

27 (Hatt, Fletcher, \& Deletic, 2009). Mechanisms for pollution removal include sedimentation, plant

28 uptake (Vought, Dahl, Pedersen, \& Lacoursière, 1994), filtration (Urbonas, 1999), biofiltration

29 (Hatt, Deletic, \& Fletcher, 2007), biodegradation, sorption and biosorption (Volesky \& Hola,

30 1995). Different types of green infrastructure better optimize some of these functions over

31 others. For example, while swales or constructed wetlands are designed to achieve both runoff

32 quantity and quality goals, filters and green roofs are primarily designed to improve water

33 quality, and rain barrels and permeable pavement aim to reduce runoff volume and/or peak flow

34 (Larson \& Safferman, 2008; US Environmental Protection Agency, 2000). Empirical studies

35 show significant variability in the performance of green infrastructure, which may be attributed

36 to a wide range of causes, from maintenance to weather to surrounding landscape (Gonzalez-

37 Meler et al., 2013). Although green infrastructure systems vary in their effectiveness, with proper

38 design and maintenance, they may provide an effective complement to conventional stormwater

39 infrastructure.

There has been, however, little examination of how green infrastructure interacts with the

41 other components in the hydrological system, including roads and sewers, and their collective

42 impact on the stormwater hydrology of an urban area. Empirical studies to this effect are costly

43 and difficult to carry out because of the very nature of the experiment. Urban neighborhoods are

44 unlikely to share land cover, gray infrastructure, and even rainfall intensity in the same storm.

45 Consistent implementation and maintenance of green infrastructure would also have to be

46 ensured for appropriate comparison across neighborhoods. Given the expense of such 
47 experimentation, numerous modeling tools have been created for planners and engineers to

48 model stormwater runoff and water quality, ranging from simple site-specific, spreadsheet-based

49 models that estimate runoff amounts, to data-intensive, watershed-scale models with multiple

50 catchment areas that are capable of giving precise estimates of runoff and water quality, used to

51 guide the construction of entire water management systems. These tools are all designed to

52 address a variety of purposes and thus have varying data needs, provide different levels of detail

53 in their outputs, and make assumptions about processes and spatial interactions in different ways.

54 A review of existing tools is given below, and summarized in Table 1 . We seek to expand the

55 space of possible green infrastructure solutions with modeling tools that allow us to

56 systematically experiment via simulation what would be too costly to test empirically. Our goal

57 is to help policy-makers understand how different neighborhood-level green infrastructure

58 designs may alleviate urban flooding, and contribute with generalizable strategies that can be

59 effective in a broad range of neighborhood and climate conditions. This model could ultimately

60 guide empirical testing of green infrastructure designs, once specific promising strategies are

61 identified. We developed the Landscape Green Infrastructure Design (L-GrID) model with the

62 characteristics needed for this purpose (outlined in section 1.2).

\subsection{Background: Existing Stormwater Runoff Modeling Tools}

Starting with the simplest models, spreadsheet models are designed to make simple and

65 quick estimates. The Center for Watershed Protection's Watershed Treatment Model (WTM)

66 (Caraco, 2011) and the U.S. Environmental Protection Agency's (USEPA) Spreadsheet Tool for

67 Estimating Pollutant Load (STEPL) (Tetra Tech, 2006) are both user-friendly for quick planning

68 estimates about impacts of developments in terms of runoff volume and quality. The US

69 Department of Agriculture's Urban Hydrology for Small Watersheds, Technical Release 55 (TR- 
55) (US Department of Agriculture, 1986) is one of the most widely used worksheet models. It

71 consists of a series of tables of values based on soil types and land covers, known as SCS curve

72 numbers, that planners can use to produce quick estimates of runoff at specific sites.

73 Some simple planning tools are available online and are frequently updated with new

74 information or scenarios. L-THIA (Long Term Hydrologic Impact Analysis), developed by

75 Purdue University and the US Environmental Protection Agency, is a web-based spreadsheet

76 model intended to show how land-use change affects runoff and water quality over the long term

77 ( Midwest Spatial Decision Support Systems (MSDSS) Partnership, 2010). It uses 30 years of

78 rainfall data and soil information for all counties in the Midwest, and the TR-55 tables to

79 estimate runoff for individual storms. The Green Values Calculator, developed by the Center for

80 Neighborhood Technology, is another user-friendly, web-based model that uses the same TR-55

81 tables to estimate the effect of particular developments on runoff, and focuses on comparing the

82 cost effectiveness of integrating different BMPs to reduce runoff (Center for Neighborhood

83 Technology, 2010).

Rising in level of detail and complexity, other models were developed to provide greater

85 customization for specific watersheds or development project, provide more information about

86 implementation of BMPs, and include explicit spatio-temporal processes in their simulation.

87 They tend to have more focused goals, such as sizing of BMPs or planning long-term water

88 quality. The Partnership for Water Sustainability in British Columbia’s Water Balance Model

89 (WBM) (Partnership for Water Sustainability in British Columbia, 2013) is an online tool

90 specifically calibrated for use in Canada and to plan for water quality at the site, watershed, or

91 regional scales. Spatial representation is limited by the scale defined by the user, and runoff

92 volumes are aggregated per subcatchment. RECARGA, developed by the State of Wisconsin, is 
93 intended for small watersheds as a tool to properly size bioretention and bioinfiltration facilities

94 for new developments (Atchison \& Severson, 2004). It uses the TR-55 tables in the same manner

95 as the other models to estimate the runoff entering the BMPs. The P8 Urban Catchment model

96 (Program for Predicting Polluting Particle Passage thru Pits, Puddles, \& Ponds) was developed

97 for the US Environmental Protection Agency and the States of Wisconsin and Minnesota to

98 model runoff and water quality in urban watersheds for the purpose of evaluating development

99 proposals and to select and size BMPs (Walker, 2007). It is a hybrid model, combining

100 spreadsheet and watershed components, since it uses the TR-55 tables to estimate runoff but can

101 still represent larger scales. It is, however, limited by its method of subdividing watersheds into

102 pervious and impervious zones, and a surface flow mechanism that primarily simulates the

103 routing of water through a chain of BMP devices (e.g. ponds and basins) to estimate the changes

104 in flow and water quality through the removal of pollutants and solids. It does not, however,

105 allow for spatially explicit representation of the location of BMPs.

106 Other stand-alone models require extensive data inputs and calibration. The outcomes

107 involve more detailed representation of hydrological processes and comprehensive outputs.

108 These models can often be integrated with other programs such as ArcGIS or run with extensions

109 that further fine-tune hydrological processes. The AnnAGNPS (Annualized AGricultural Non-

110 Point Source Pollution Model) was developed by the US Department of Agriculture primarily to

111 model agricultural runoffs (Bingner, Theurer, \& Yuan, 2010). It is a cellular model with user-

112 defined cell sizes. It is thus spatially explicit, allowing better representation of surface flows and

113 erosion. Besides being limited to agricultural areas, it is problematic to track data over time-

114 periods longer than a day. This model also tends to overestimate sediments, is not readily

115 customizable, and is very data intensive. WinSLAMM (the current Windows version of the 
116 Source Loading and Management Model) has been in use for nearly forty years (PV and

117 Associates, 2013). It was designed as a planning tool for sizing and placement of BMPs for

118 pollution control. Although its processes update in small time steps of at least six minutes, its

119 flow processes focus on routing and flow rates over relatively large geographies. It also requires

120 extensive field data for calibration. While it uses long-term precipitation records, it tends to

121 correct for only small storm hydrology.

122 Among more intensive data-based and spatially-explicit watershed-scale models, the

123 SWMM (Stormwater Management Model) is more frequently used. The US Environmental

124 Protection Agency developed this tool to model sewer capacities over large scales by using

125 subcatchment areas (Rossman, 2010). Landscapes in SWMM are divided into subcatchments and

126 drainage networks. Processes can use time steps that are controlled by the user and can be

127 smaller than a minute. Despite its widespread use, its limitations include a laborious setup of the

128 drainage network and configuration process, and a limited ability to customize land coverages

129 and to handle water quality. Its surface flow mechanism focuses on sewer drainage or flow to

130 BMPs. Although users have control over sizing of subcatchments, it is time-intensive to create a

131 subcatchment network with a fine enough resolution to investigate how small local variations in

132 elevation, land cover, soils, or BMP placement affect runoff or lead to flow between

133 subcatchments. One final watershed model, the System for Urban Stormwater Treatment and

134 Analysis Integration Model (SUSTAIN) was developed for the USEPA to aid in placement and

135 sizing of BMPs to meet cost, water volume, and water quality goals (Shoemaker, 2009). It is as

136 data-intensive as SWMM, but it has a more user-friendly interface for managing the layout of the

137 landscape and BMPs. It is also similar to SWMM in its representation of hydrological processes,

138 but its runoff measurement focuses on single sites within subcatchments, or "assessment points," 
139 which are located in the lowest points of subcatchments. It thus narrows the assessment of

140 impacts to these points. Like SWMM, it also requires extensive calibration and hydrological

141 modeling expertise to run (Lee at al., 2012).

\section{$142 \quad 1.2 \quad$ The Case for a Different Model}

While the tools described above are useful for the purposes for which they were created,

144 they become harder to use to derive principles of green infrastructure design across urban

145 neighborhood landscapes (i.e. beyond a site, but within the regional subcatchment scale) and

146 storm conditions. Existing policies are based on unexamined assumptions about the effectiveness

147 of green infrastructure, and require performance standards that may either not be attainable, or

148 may be attainable at the site level but not solve the problem at the neighborhood level because

149 they do not take into consideration spatial interactions during a storm. At the request of the

150 Illinois Environmental Protection Agency, we sought to provide a tool to rapidly and

151 systematically explore the effects of standards and guidelines to manage urban runoff, without

152 the expense and highly technical expertise involved in calibrating a predictive tool to a wide

153 range of conditions, or in empirical testing. Such tools are needed to inform the development of

154 planning and regulatory recommendations for stormwater management with a fuller

155 understanding of how green infrastructure may work (or not) in a variety of situations.

156 The specific research questions driving our work are organized in two parts. The first

157 relates to the ideal proportion of green infrastructure on the landscape and whether there is a

158 threshold beyond which the benefits of adding green infrastructure are marginal. The second set

159 of questions relates to how the spatial configuration of green infrastructure over the landscape

160 matters. To investigate these questions, we required a spatially explicit model that simulated how

161 stormwater flow and accumulation is affected by different green infrastructure configurations in 
162 a variety of physical landscapes (e.g., slope, soil permeability) and storm characteristics. Thus,

163 we required a high-resolution dynamic model that allowed non-modelers to easily experiment

164 with green infrastructure placement, and that was friendly, fast and flexible enough that users

165 could enter either real or hypothetical landscapes and scenarios, and translate the outputs into

166 policy guidelines applicable to a variety of conditions. We wanted to recreate the ease of data

167 input and tractability found in the simpler tools, and the spatio-temporal explicitness of the more

168 complicated models, i.e. simpler and tested flow algorithms on more detailed landscapes. Recent

169 studies have stressed the need for such parsimonious modeling tools for green infrastructure

170 planning (Yang et al., 2015; Martin-Mikle et al., 2015).

171 To satisfy the requirements above, we built the Landscape Green Infrastructure Design

172 (L-GrID), which allowed us to run a number of different green infrastructure scenarios varying

173 in storm and landscape characteristics, and compare the outcomes in terms of flooded area and

174 runoff volume. In the next sections, we describe the components and mechanisms of L-GrID, the

175 simulation scenarios and results, and discuss implications for planning and policy.

\section{Model Components and Processes}

\section{$177 \quad 2.1 \quad$ Model Overview}

178 L-GrID is a cellular model created in Netlogo (Wilensky, 1999). It was originally

179 designed for the Illinois Environmental Protection Agency to investigate the effects of different

180 green infrastructure configurations on urban stormwater management on a neighborhood scale.

181 We chose to model a single, stylized form of green infrastructure that incorporates features

182 common to various types, mainly the capacity to infiltrate and store stormwater. The model

183 allows users to modify storm duration, landscape size, placement of green infrastructure, sewer

184 configuration, and coverage ratios for different land cover types. After the configuration is set, 
185 the user can run simulations and compare the outcomes in terms of flooded area and runoff

186 volumes directed to sewers, green infrastructure, and adjacent areas. L-GrID was specifically

187 designed to run simulations to compare the effectiveness of different scenarios of green

188 infrastructure allocation for stormwater management in a landscape, thus allowing us to derive

189 generalized principles for green infrastructure configuration at a neighborhood or regional scale.

190 L-GrID was not designed to predict stormwater runoff for a specific region, and should not be

191 used in this manner. The predictive models described in section 1.1 are better equipped for that

192 purpose.

\section{$193 \quad 2.2$ Landscape}

The landscape is represented as a two-dimensional lattice of cells that are $10 \mathrm{~m} \mathrm{x} 10 \mathrm{~m}$

each. We chose this resolution based on the width of our simulated streets, the narrowest

196 channels through which stormwater could flow. The default landscape size for our simulations is

197 a 200 x 200 cell grid or a lattice representing $4 \mathrm{~km}^{2}$. Global variables describe characteristics that

198 apply uniformly to the entire lattice. These include the time series for precipitation, based on

199 storm magnitude and duration, and evaporation and evapotranspiration rates (Table 2). Cell

200 variables describe the attributes of each cell relevant to infiltration and flooding. These include

201 land cover, soil type associated to the land cover, and hydrological coefficients related to soil

202 type (Table 3). We based our assumptions loosely on Cook County, Illinois, in which most of the

203 city of Chicago is located. Although Cook County has 33\% impervious cover (Cook \& Iverson,

204 2000), we used 50\% impervious coverage as a default value for our simulations because the

205 county contains large areas of forest preserves and parkland, and we focus here on stormwater

206 management in urban neighborhoods. Part of this cover is dedicated to roads, which also contain

207 sewers. The proportion of green infrastructure in the landscape is a parameter that defines, in 
208 part, our scenarios (see section 3). The remaining area is permeable surface. The following

209 subsections describe the various landscape attributes in more detail.

\subsubsection{Land Cover}

211 Cells in the landscape are one of two basic cover types: impervious surface (e.g. roads,

212 buildings, parking lots), or permeable surface (e.g. lawns, parks, undeveloped land) (Figure 1).

213 For the various scenarios, green infrastructure land cover can be placed on permeable cells only.

214 The soil type associated to each land cover type determines the average capillary suction,

215 saturated hydraulic conductivity, and initial moisture deficit (Oram, N.d.), and they all affect

216 infiltration rates (see section 2.3.2, Table 3). Impermeable surfaces do not allow infiltration.

217 Permeable surfaces are assumed to be silty clay loam soils, which are the dominant soil type in

218 Cook County and have moderate-to-low permeability (Krumm, Nelson, \& Beaverson, 1984).

219 Green infrastructure soils are typically engineered to contain between $85 \%$ and $88 \%$ sand for

220 optimal infiltration (Hunt \& Lord, 2006). Thus, in our model, the soil of cells containing green

221 infrastructure is assumed to be loamy sand. In addition to enhancing infiltration, many types of

222 green infrastructure (with the notable exception of permeable pavement) are built to allow some

223 detention or retention of water on the surface. Accordingly, cells with green infrastructure have

224 their elevation lowered by $200 \mathrm{~mm}$ to simulate this storage capacity. This value was within the

225 range of depths of infiltration devices used in urban areas, excluding wetlands and detention

226 basins (Gonzalez-Meler et al., 2013). The green infrastructure’s engineered soil extends to 1,019

$227 \mathrm{~mm}$ below the elevation, for a combined depth of $1,219 \mathrm{~mm}(4 \mathrm{ft})$ from the land surface, which is

228 recommended for optimal pollutant removal and cost effectiveness (US Environmental

229 Protection Agency, 1999; Hunt, 2006). For simplicity, we assumed the same total combined

230 depth of the soil $(1,219 \mathrm{~mm})$ for permeable cells as for green infrastructure, based on the average 
231 depth to the water table in Cook County, Illinois (Morrow \& Sharpe, 2009). For our purposes of

232 generalization, we modeled stylized green infrastructure with common attributes rather than

233 specific types, assuming that all green infrastructure installations are well maintained and thus

234 perform with equal effectiveness and according to specifications. Table 3 summarizes the

235 parameter values for both land cover types and for cells with green infrastructure.

\section{$236 \quad$ 2.2.2 Slope and Outlets}

237 The landscape has a slope of $0.25 \%$, which is within the range of what is observed in

238 Cook County (Illinois State Geological Survey, 2011). In our default scenario, the slope is

239 oriented toward the lower left-hand corner of the lattice, where a primary outlet allows surface

240 runoff to leave the landscape. Additional secondary outlets exist at intersections along the left

241 and bottom side of the landscape (see 2.3.7). Without secondary outlets, the landscape would

242 essentially work as a detention basin (Figure 1).

\section{$243 \quad$ 2.2.3 Roads and City Blocks}

244 Urban landscapes are engineered to direct water toward drains, with roads designed to be

245 the primary conduit for surface water to reach sewer intakes. It was important to mimic this basic

246 design concept. Roads in our landscape are 10 meters (or 1 cell) wide, surrounding city blocks

247 that are $200 \mathrm{~m}$ x $100 \mathrm{~m}\left(20 \times 10\right.$ cells, or $\left.20,000 \mathrm{~m}^{2}\right)$, the approximate size of city blocks in

248 Chicago (Figure 1). Blocks are assumed to have curbs with a height of $150 \mathrm{~mm}$, the average

249 height required by the City of Chicago and the State of Illinois (City of Chicago, 2007), but due

250 to the fact that roads are graded to be higher in the center in order to direct stormwater to the

251 edges, a height of $127 \mathrm{~mm}$ is used to simulate the reduced area for street storage that the grading

252 creates. Therefore, road cells are $127 \mathrm{~mm}$ lower than other cells. Curbs direct runoff from 
253 impermeable surfaces toward sewer intakes on the streets. If a green infrastructure cell is located

254 next to a road however, it acts as a curb cut due to its lower elevation (see section 2.2.1), and

255 allows water to flow off the street and into the green infrastructure's surface water detention

256 area. Under this condition, sewers and green infrastructure would compete for surface runoff

257 water. In practice, stormwater does not flow unimpeded through the landscape and down the

258 streets to its outlets. A common strategy is to build street berms to contain the runoff locally and

259 prevent excessive flow downstream, as mandated by Illinois law (Carr, Esposito, \& Walesh,

260 2001). In L-GrID, the downstream neighboring road cells from road intersections are thus raised

$261101.6 \mathrm{~mm}(4 \mathrm{in})$.

$262 \quad 2.2 .4$ Sewers

263 Sewer intakes are located on each road, at 5 cell intervals (Figure 1). This arrangement is

264 based on our own surveys of several streets in the neighborhoods around the campus of the

265 University of Illinois at Chicago. Cells with sewer intakes each have a manhole that locally

266 stores some of the water that flows into the drains. The volume of the manholes in the model is

$2672.18 \mathrm{~m}^{3}$, which is the volume of a typical basin in the Chicago region (John Watson,

268 Metropolitan Water Reclamation District of Greater Chicago, personal communication, October

269 17, 2014) (Figure 2). The sump, or the volume of the manhole below the outlet pipe, is 25\% of

270 the total manhole volume. Outlet pipes are assumed to have a diameter of $45 \mathrm{~cm}$. Water does not

271 begin to enter the sewer system until it reaches the outlet pipe height, and water stored below the

272 pipe inlet stays there for the duration of the simulated storm. 


\subsection{Processes and Order of Events}

Processes represented in L-GrID are the ones identified in the literature as most relevant

275 to the performance of green infrastructure for stormwater management (see Section 1). The

276 processes run in the following order: 1) precipitation, 2) infiltration, 3) sewer intake, 4)

277 evaporation, 5) evapotranspiration, 6) surface flow, and 7) drainage through the outflow (Figure

278 3). Each sequence runs in time intervals of 30 seconds until stop conditions are met, as detailed

279 in section 2.3.8. Sensitivity tests showed that, for the current spatial resolution, the model

280 produced continuous flow when the temporal resolution was 30 seconds or less; the fastest flow

281 processes at this spatial scale were adequately represented. Longer time steps led to

282 discontinuous flow and, similar to other numerical approximation hydrological models, would

283 require larger cell sizes. Our focus on discrete storm events led us to dismiss groundwater

284 recharge and flow. The soil type and flat slope of northeastern Illinois would result in little 285 appreciable movement of infiltrated water over single storm event, vertically or horizontally

286 (Howard Reeves, US Geological Survey, personal communication, April 8, 2010).

\section{2.3.1 Precipitation}

288 Test runs were conducted for 24-hour storm events of 5- and 100-year magnitude, the 289 former being the design storm for new sewer construction, while the latter has increased in 290 occurrence in the last few years. Other urban areas besides Chicago are experiencing similar 291 effects of climate change, raising concerns among state legislators and local policy makers about 292 how to best handle these effects (Jaffe, et al., 2010).

293 Precipitation rates were calibrated for Chicago, Illinois (National Oceanic and

294 Atmospheric Administration, 2014). A 24-hour duration 5-year storm has a precipitation total of $29595.76 \mathrm{~mm}$ (3.7 in). A 24-hour 100-year storm has a precipitation total of $182.88 \mathrm{~mm}$ (7.2 in). The 
model uses an input table to simulate the rainfall rate at each time step, corresponding to a

297 triangular hyetograph, where the peak rainfall rate occurs one third of the way through the storm

298 and the peak is twice the average intensity (Akan, 1993; Yen \& Chow, 1980) (Figure 4).

299

300

301

302

303

304

305

306

307

308

309

310

311

312

313

314

315

317

316 Only green infrastructure and permeable surface cells can infiltrate water. During model

\subsubsection{Infiltration}

Infiltration rates are calculated using the Green-Ampt formula (Albrecht \& Cartwright, 1989; Green \& Ampt, 1911), which is used by many of the existing watershed models, including SWMM and RECARGA. An advantage of Green-Ampt over other methods, including the TR-55 SCS curves, is that it allows for estimates of infiltration rates over time, and takes into account the soil type and amount of water that has already infiltrated in previous time steps.

On the first iteration only, infiltration is equal to the rainfall rate. The high proportion of impervious surface immediately produces runoff and water accumulation or ponding. In these conditions, the infiltration rate for subsequent time steps until saturation is calculated as follows:

$$
f=K_{s}\left[1+\frac{\left(\theta_{s}-\theta_{i}\right) \psi_{f}}{F}\right]
$$

where:

$\mathrm{f}=$ infiltration rate at time $\mathrm{t}(\mathrm{cm} / \mathrm{s})$;

$\mathrm{F}=$ total amount of water infiltrated at time $\mathrm{t}(\mathrm{cm})$;

$\mathrm{K}_{\mathrm{s}}=$ saturated hydraulic conductivity $(\mathrm{cm} / \mathrm{s})$;

$\Psi_{\mathrm{f}}=$ suction at wetting front (negative pressure head, $\mathrm{cm}$ );

$\theta_{\mathrm{i}}=$ initial moisture content;

$\theta_{\mathrm{s}}=$ saturated moisture content. initialization, each cell will have computed and stored the maximum amount of water that can 
318 infiltrate over the course of the storm, corresponding to the cell's land cover, soil type, and soil

319 depth to the water table. While the wetting front does not reach the water table depth, each cell

320 calculates at each time step the maximum amount of water that can infiltrate given the soil type

321 and current degree of saturation. The actual amount of precipitation that infiltrates is the volume

322 on the surface of the cell, up to the calculated maximum. The engineered soils of green

323 infrastructure are designed to have more than sufficient capacity to infiltrate all the water that

324 falls on them during a range of 24-hour storm in the Chicago region, including 100-year storms.

325 The green infrastructure soils have extra capacity to retain runoff from surrounding pervious and

326 impervious areas. However, once completely saturated, the green infrastructure itself will

327 produce runoff.

328

329

330

331

332

333

334

335

336

337

338

339

340

\subsubsection{Sewer Intake}

Sewer intakes in the Chicago area are designed to capture stormwater at a rate of 1.2 cubic feet per second $\left(0.034 \mathrm{~m}^{3}\right.$ per second). Most intakes tend to be blocked by $50 \%$ (John Watson, Metropolitan Water Reclamation District of Greater Chicago, personal communication, October 17, 2014), so that the sewer intake rate in L-GrID is set to $0.51 \mathrm{~m}^{3}$ per 30 -second time step. After the water level in the manhole reaches the outlet pipe, it enters the sewer system at the same rate as it enters the basins from the streets. Since our focus was on spatial interactions of the water on the landscape and not in the pipes, L-GrID assumes that the water that enters the sewer system is processed by treatment plants, but does not represent the transport and treatment explicitly. The treatment rate is based on operating data for the Stickney Water Reclamation Plant, a Metropolitan Water Reclamation District facility near Chicago and one of the largest treatment plants in the world. The plant handles water for an urbanized area that covers 673.4 $\mathrm{km}^{2}$, and has an average daily capacity of over 4.5 million $\mathrm{m}^{3}$ of water (Metropolitan Water 
341 Reclamation District, 2009). This translates into $9.37 \mathrm{~m}^{3}$ of runoff per time step being removed

342 from the simulated sewer system for treatment, thus freeing up capacity for further sewer intake

343 (Table 2).

344 In Chicago, the sewer system is ideally engineered to handle 24-hour, 5-year storms

345 without backing up or producing combined sewer overflows (CSOs). In practice, however, due

346 to ageing infrastructure and other constraints, the sewer system can accommodate 24-hour 2-year

347 storms without flooding or CSOs (John Watson, Metropolitan Water Reclamation District of

348 Greater Chicago, personal communication, November 14, 2014). We did not consider CSOs in

349 our scenarios, so that we could assess under what conditions green infrastructure could prevent

350 their occurrence. Without CSOs, if the assumed sewer infrastructure is full, the sewer intake rate

351 is reduced by $98.2 \%$, to the rate at which the treatment plant removes water from the sewers

352 (Table 2). To determine how much water the sewer infrastructure would handle before

353 saturating, the model was run with a 24-hour, 2-year storm, which has a total precipitation of

$35477.216 \mathrm{~mm}$ (Angel, 1989), with 0\% green infrastructure and 50\% impervious cover, an

355 approximation of land cover conditions in Chicago. The maximum volume of water in the

356 simulated sewer infrastructure at any time was used as an approximation for the sewer capacity

357 for all simulation runs presented here. The maximum sewer volume for this landscape was

$358141,560 \mathrm{~m}^{3}$. For a landscape of different size or land cover, or for a different sewer and treatment 359 system, this maximum volume would need to be recalculated.

\subsubsection{Evaporation}

After the 24-hour storm event is over, evaporation occurs in all cells, regardless of cover

362 type. We use rates derived from pan evaporation rates, an estimate used by other models,

363 including SWMM and RECARGA. In Illinois, the State Climatologist Office collects 
364 evaporation data from sites around the state. The only site located in northeastern Illinois is

365 located at the Chicago Botanic Gardens and has data from 1997 to 2008 (Illinois State

366 Climatologist Office, 2008). We chose to use the average monthly evaporation for June because

367 its rate is closest to the average rate for summer months, the season when $65 \%$ of the top-ranked

368 1-day storms in Illinois occur (Huff \& Angel, 1992). The monthly evaporation rate is 142.748

369 mm, which was multiplied by 0.75 , as recommended by the State Climatologist’s Office, to

370 compensate for higher evaporation due to ideal pan conditions, resulting in an adjusted average

371 daily evaporation rate of $3.5625 \mathrm{~mm}$.

\section{$372 \quad$ 2.3.5 Evapotranspiration}

373 Water evapotranspires from all green infrastructure cells at a set rate of 5.8E-4 mm per

374 30-second time step, an average of reported data from several types of green infrastructure

375 installations (e.g., Lazzarin, Castellotti, \& Busato, 2005; Li, et al., 2009). Different types of

376 vegetation may have different evapotranspiration rates, but here we use the same average rate for

377 all cells as representative aggregates of many types of vegetation present in green infrastructure.

\section{$378 \quad$ 2.3.6 Surface Flow}

379 The process of surface flow computes flow volumes between cells by solving Manning’s

380 equation for volume, adapting the equations for shallow concentrated flow when flow occurs

381 between block cells, and to open channel flow when flow is between road cells (equations 2 and

382 3) (US Department of Agriculture, 1986). Each iteration, cells are ordered in ascending order of

383 elevation, and interact with each one of its upstream neighbors, also in ascending order of

384 elevation. This order of events for flow ensures that water can travel at most one cell per time

385 step. The amount of flow between cells ordered in this way is determined by Manning's 
equation, which is a function of hydraulic slope, surface roughness, and water depths in a cell

387 and its neighbor. Backwater flow naturally happens when lower elevation cells have higher

388 hydraulic heads than their upstream neighbors. L-GrID limits this flow to not exceed the

389 equilibrium water level between two neighboring cells (Ben O’Connor, University of Illinois at

390 Chicago, personal communication, February 14, 2014) (equation 2). If water depth is greater

391 than $24.5 \mathrm{~mm}$ (1 in), the Manning's roughness coefficient is halved to represent the reduction in

392 friction from the underlying surface cover (Ben O’Connor, University of Illinois at Chicago,

393 personal communication, February 14, 2014) (equation 3).

$$
Q=v \times A
$$

395 where:

$396 \quad Q=$ flow volume per unit time;

$397 v=$ velocity (from equation 3 ), and

$398 A=$ cross sectional area, computed as $w \times c$, where $w$ is the smallest of: (1) the water depth of

399 the cell from which water is flowing, or (2) half of the difference in the cells' heads, and $c$ is: (1)

400 the channel width for road flow, or (2) the distance between the center of each cell and its

401 neighbor for shallow flow on the blocks.

402 Velocity in equation 2 is computed as follows:

$$
V=1 / n \times r^{2 / 3} \times s^{1 / 2}
$$

404 where:

$405 r=$ hydraulic radius, calculated as $A / p$ for open channel flow in roads, where $p$ is the wetted 406 perimeter of the cell from which water is flowing, or as $w$ for shallow concentrated flow over 407 blocks (Ben O’Connor, University of Illinois at Chicago, personal communication, February 14, 408 2014); 
$409 s=$ hydraulic slope between the cell and its neighbor, and

$410 n$ = Manning's roughness coefficient, according to the cell's land cover (Table 3) and up to a

411 water depth of $25.4 \mathrm{~mm}$; at deeper water levels, the roughness coefficient is halved.

\section{$412 \quad$ 2.3.7 Outlet Drainage}

413 The outlet cells function as a drain for runoff. The model uses Manning's equation for

414 open channel flow (equations 2 and 3), to determine outlet flow volumes. The slope is the same

415 as between the outlet cell and its neighboring upstream road cell in the direction of outflow,

416 assuming that the road continues with the same slope beyond the outlet. Water is discharged at

417 this rate through each outlet cell and away from the system. The outlet product of the model is

418 used as an estimate of runoff discharged downstream of the area simulated. The primary outlet

419 on the lower left corner of the landscape will contribute a higher share of runoff than any other

420 secondary outlet, being the lowest point at which runoff leaves the system.

\section{$421 \quad 2.3 .8 \quad$ Stop Conditions}

422 After a storm event, the model will run for up to one additional day but will stop earlier if 423 all accumulated water leaves the surface. Once each simulation is completed, the model reports

424 the volume of water leaving the system by the various mechanisms described above (e.g.,

425 infiltration via green infrastructure and soils, evaporation, evapotranspiration, etc.).

426 Evapotranspiration, often stressed as an important advantage of green infrastructure, had a very

427 minor effect on our outputs of interest within single storms, and was thus not further included in

428 our analyses below. We note, however, that this mechanism becomes more important in the long

429 run, as it reduces soil water content and increases infiltration capacity in between storms. 


\section{Scenarios and Simulation Results}

We conducted simulations to compare the effectiveness of different green infrastructure

432 configurations for stormwater management in urbanized neighborhoods. We evaluate each

433 scenario in different ways, to provide a fuller picture of the stormwater problem and how each

434 allocation scenario might address this problem in multiple dimensions. All scenarios are

435 evaluated relative to a baseline, without any green infrastructure for the first set of simulations

436 (section 3.1), or with random placement for the second set (section 3.2). Our metrics include: (1)

437 the amount of water infiltrated by green infrastructure, (2) the volume of runoff directed to the

438 sewer system ("sewer runoff"), (3) the volume of runoff flowing to outside areas through the

439 outlet cell ("outlet runoff"), and (4) the maximum area flooded. To determine if a cell is flooded,

440 each cell records its greatest water depth during a run. Road cells or green infrastructure cells on

441 road curbs are considered flooded at $50.8 \mathrm{~mm}$ (2 in), while block cells are flooded at $24.5 \mathrm{~mm}$ (1

442 in), the threshold at which damage is expected to start to accrue in each case (John Watson,

443 Metropolitan Water Reclamation District of Greater Chicago, personal communication,

444 November 8, 2013). We measure flooding of green infrastructure cells from the top of its surface

445 storage, i.e., from where the cell elevation would have been without the green infrastructure (see 446 section 2.2.1).

447 The default settings used in all scenarios are listed in Table 4; variables in bold show the

448 variables that changed across scenarios. Sensitivity tests showed that the effect of randomness in 449 initial land cover allocation tends to cancels out in larger landscapes, producing little variability 450 across runs. All scenarios were thus run only one time to reduce computation time. All scenarios 451 were also tested for both 5-year and 100-year storms. 


\subsection{Proportion of Green Infrastructure on the Landscape}

Our initial hypothesis was that there are optimal proportions of green infrastructure with

454 respect to other cover types, so that beyond a certain threshold the improvements would only be 455 marginal. We also expected that, since the sewer systems are calibrated to handle 2-year storms, 456 there would be much lower levels of flooding or sewer intake after a 5-year storm in absence of 457 green infrastructure. With more intense 100-year storms, however, green infrastructure would 458 help manage stormwater and minimize the burden on the sewer systems and the neighborhood.

459 To explore these questions, we conducted model runs using the default conditions, varying the 460 percentage of cells that are dedicated to green infrastructure (Table 4). We placed green 461 infrastructure in cells sorted in descending order by number of upstream impervious neighbors, 462 until the target green infrastructure cover was reached for each scenario $(0 \%, 10 \%, 20 \%, 30 \%$, $46340 \%$, and 50\%). Since the initial allocation of land covers is random, so is the resulting green 464 infrastructure scenario.

Our simulations show that at around $10 \%$ of green infrastructure coverage, more water 466 would be directed to green infrastructure than to sewers in 5-year storms, and all surface flooding 467 and runoff to downstream areas would be eliminated (Figure 5). At around 20\% of green 468 infrastructure coverage sewer intake begins to level off, and the marginal benefit of adding green 469 infrastructure beyond $20 \%$ begins to decrease.

470 At least 10 - 15\% green infrastructure coverage would be needed to outpace the sewers 471 and the discharge downstream in larger storms, and to significantly reduce block flooding. Road

472 flooding would require $20 \%$ coverage to be reduced. At about $30 \%$ coverage, green

473 infrastructure would begin to alleviate the sewer system from operating at full capacity and 474 eliminate downstream outflow (Figure 5). The overall marginal benefit of adding green 
475 infrastructure greatly decreases at higher values, although it would free up treatment and storage

476 capacity in the sewer system.

\section{$477 \quad 3.2 \quad$ Spatial Placement of Green Infrastructure}

The simulations described above allowed us to identify a range of values for green

479 infrastructure cover that would have the greatest effectiveness over different storm types: 5 -

$48015 \%$ coverage for 5 -year storms, and $15-30 \%$ coverage for 100 -year storms. We proceeded by

481 exploring the influence of spatial configuration within this range of cover on the ability of green

482 infrastructure to handle stormwater generated by both 5-year and 100-year storms. This range

483 also better aligns with the reality of most urban areas: limited space and funding to invest in

484 stormwater management.

485 We organized our discussion first around archetypical configuration scenarios, often

486 discussed in environmental planning circles, to examine how specific locational characteristics

487 might influence the simulation results, against our sorted random baseline. Traditional

488 stormwater management directs rainwater towards the streets, which act as stormwater collectors

489 due to their lower elevation, and in turn direct the runoff towards sewers. One type of low impact

490 development includes creating curb cuts to allow water on the streets to flow into green

491 infrastructure. We expected that having green infrastructure adjacent to roads would produce

492 better outcomes by allowing these structures to compete with sewers for water, thereby reducing

493 the burden on the sewer system and flooding. To explore this effect, we created two scenarios:

494 one with green infrastructure placed only adjacent to roads and one with green infrastructure

495 placed away from roads. Green infrastructure located downstream is also expected to intercept

496 and infiltrate more of the water as it flows down the slope toward the primary outlet, especially

497 in more intense storms. While this may be true, one argument for placing green infrastructure 
498 upstream is to prevent the production of runoff that will end up accumulating in downstream 499 locations.

$500 \quad$ Running the model with archetypical green infrastructure scenarios allowed us to

501 examine how specific layouts perform differently for the various ways in which water flows and 502 accumulates in a range of storms. With this in mind, we designed a hybrid layout that combines 503 the perceived benefits of locating green infrastructure adjacent to roads, the concentration of 504 these structures downstream, and the dispersion of structures upstream in the landscape. In this 505 scenario, $10 \%$ of the total green infrastructure is located downstream, $45 \%$ is scattered upstream, 506 and $45 \%$ is located along roads in the middle section of the landscape.

507 We present in the next section the simulation results of all the scenarios we tested for 508 smaller and larger storms: (1) sorted random (baseline), (2) adjacent to roads (curb cuts), (3) 509 away from roads, (4) upstream, (5) downstream, and (6) hybrid (Figure 6). We conducted 510 sensitivity tests around assumptions of green infrastructure storage capacity, and found that the 511 results are robust within the range of $100 \mathrm{~mm}$ to $300 \mathrm{~mm}$ storage capacity (depth).

\section{$512 \quad$ 3.2.1 Effects of placement in smaller storms}

513 In smaller storms, clustering green infrastructure downstream or upstream was similarly

514 ineffective in reducing sewer runoff (Figure 7). Concentrating green infrastructure reduces its

515 effectiveness in routing runoff away from the sewer system, while spreading it out in the 516 landscape increases exposure, storage and infiltration. For this reason, with lower amounts of 517 precipitation, scattering green infrastructure eliminated flooding in the simulated landscape and 518 runoff to neighboring areas, and reduced sewer intake. It is worth noting that even at $5 \%$ 519 coverage, improvements are already noticeable. Among the dispersed scenarios, increasing 520 coverage results in greater effectiveness in diverting water from the sewer system towards 
521 infiltration, by those layouts that include curb cuts (baseline, adjacent to roads and hybrid)

522 relative to the layout without (away from roads).

\section{$523 \quad 3.2 .2$ Effects of placement in larger storms}

$524 \quad$ In the larger storms and at lower levels of green infrastructure coverage, the landscape

525 flood depths frequently exceeded the $127 \mathrm{~mm}$ curb height, thus overwhelming the green

526 infrastructure irrespective of its configuration (Figure 8). This reduced effectiveness can be

527 partially compensated by increasing green infrastructure coverage, which needs to be at least

528 doubled to obtain results closer to those generated in smaller storms. Sewers are less capable of

529 capturing all precipitation in larger storms, and runoff instead floods the landscape and is

530 directed to neighboring areas through the outlets. In all levels of coverage, upstream and

531 downstream clustering scenarios perform poorly compared to the dispersed scenarios. At $20 \%$

532 coverage and above, green infrastructure adjacent to roads shows an advantage over other

533 dispersed patterns by greatly reducing neighborhood flooding, followed by the hybrid and

534 baseline scenarios. Simulated time series with L-GrID confirm the increased capacity of layouts

535 with curb cuts to handle runoff peaks by effectively coordinating with the sewer system, both

536 routing water towards sewers and slowing down intake. At 25\% and above, however, the hybrid

537 scenario is more successful in diverting runoff from both sewers and the outflow into

538 neighboring areas. While very effective, placing green infrastructure adjacent to roads also

539 directs more water towards roads, and therefore contributes to sewer intakes (desirable) and

540 outlet flows (less desirable). The hybrid and baseline scenarios allow for water to be diverted

541 from the streets via curb cuts, but also intercepts water before it reaches the roads and, in the

542 hybrid layout, before it reaches the neighborhood downstream. For this to have an impact,

543 however, higher green infrastructure coverage is needed. 
The above simulations suggests that dispersion of green infrastructure throughout the

545 landscape is a better strategy than increasing clustering and connectivity, taking fuller advantage

546 of excess storage and infiltration capacity to capture runoff from adjacent land cover types.

547 Among the dispersed scenarios, locations adjacent to roads seem to provide the greatest

548 advantage for both storm types, particularly when there are few locations available to install

549 them. Since curb cut installations do not encroach on private property, this layout has the added

550 benefit of greater flexibility for installation, as well as increased guarantees of appropriate

551 maintenance by public agencies, rather than relying on private owners. As opportunities for

552 adding green infrastructure increase - and as storm severity increases - a hybrid approach can be

553 built on an underlying layout of curb cuts. If space constraints prevented any of these layouts,

554 random placement would still provide benefits over the remaining layouts.

\section{Implications and Future Work}

556 We aimed to explore assumptions about the effectiveness of green infrastructure, and

557 identify some general design principles for green infrastructure placement in urban areas. We

558 developed L-GriD to explore some of these questions through simulation, and inform policy

559 about green infrastructure allocation for stormwater runoff management in an urbanized

560 landscape. It is difficult and costly to empirically contrast the effectiveness of green

561 infrastructure layouts across neighborhoods that vary in landscape characteristics, infrastructure

562 placement opportunities and constraints, and storm exposure. These same challenges make

563 model validation, which should ideally follow model development, expensive and difficult to

564 control. L-GrID could be validated at a smaller scale, using the model itself to design the field

565 experiments to generate the data needed. It would not be possible, however, to account for

566 critical neighborhood-level spatial interactions. In the absence of better data, models like L-GrID 
567 can still guide policy informed with the best of our knowledge (Yang et al., 2015). According to

568 the dynamic and spatial interactions represented in L-GrID, green infrastructure could effectively

569 assist in diverting stormwater from the sewer system and prevent flooding. Moreover, some

570 layouts have greater potential to alleviate flooding than others. These findings may be used as

571 reference for green infrastructure design.

$572 \quad$ Results presented here suggest that benefits of green infrastructure are seen at a minimum

573 threshold of land area used for green infrastructure, but the marginal benefits start to decrease

574 after a certain amount is allocated in the landscape. Our simulations suggest that these cover area

575 thresholds exist, but we stress that the thresholds presented here are hypothetical. Further

576 simulation and empirical research should be conducted to estimate these values on a given

577 landscape.

578 It is important to assess the effectiveness of these approaches in a variety of both climate

579 and landscape conditions, as a higher occurrence of 100-year storms has been observed in recent

580 years, and as policy is designed and implemented at higher levels of enforcement. To ensure the

581 robust performance of green infrastructure at the landscape level, and to reduce water flow into

582 sewers and downstream areas for a variety of storms, a combination of configurations that

583 conform to landscape heterogeneity should likely be promoted, but simpler approaches may still

584 be effective. For instance, locating green infrastructure adjacent to roads, and particularly close

585 to sewer outlets, would enhance the performance of green infrastructure in a range of storm

586 types, and reduce the burden on sewer systems and areas outside the focal neighborhood. As

587 precipitation increases and with greater opportunities for green infrastructure placement, a hybrid

588 approach that follows the flow and accumulation of water in the landscape promises to be more

589 effective. These implications are in line with the recommendations of another recent study to 
590 locate green infrastructure along the flow path of stormwater (Yang et al., 2015). If such targeted 591 allocations were not possible (e.g., due to utility constraints or neighbors’ opposition), even

592 random placement (the baseline scenario) would still provide some alleviation, particularly 593 compared to large neighborhood clusters. If, due to space limitations, clustering were inevitable, 594 downstream placement should be favored over upstream placement.

595 In its current version, L-GrID can be used to test other scenarios and incorporate 596 variability and heterogeneity in the landscape (e.g., different land cover arrangements, varying 597 slopes). The model could also be transferred to other regions and infrastructure specifications by 598 changing the relevant default parameters, such as the sewer and treatment capacity, precipitation 599 rates, and soil-related and green infrastructure storage and infiltration rates. It should be 600 emphasized that deriving a "best solution" cannot be done through simulation alone, however.

601 Increased effectiveness is not always attainable across all variables of interest, especially if costs 602 (e.g., installation, operation, damage) are considered, which can widely vary in space (including 603 the downstream neighborhoods) and across scenarios. Utility constraints are also present in 604 actual landscapes, limiting placement options. The modeling tool in its current version allows 605 for such discussions to take place with an appreciation of the tradeoffs of each placement 606 strategy, within a range of biophysical contexts, including landscape characteristics, spatial 607 constraints, and stakeholder values.

608 Significant, but possible, model extensions would be required to include aspects of water 609 quality of the stormwater runoff. Having explicitly modeled water flow, chains of devices, 610 pollutant dilution, flow, and removal can be incorporated in a future version of L-GrID. Further 611 development could also include individual agents (e.g., residents and developers) making 612 decisions about green infrastructure placement, as they respond to incentives and policies that 
613 might directly or indirectly target green infrastructure. Given that the hybrid and road-adjacent

614 placement of green infrastructure seem to be the most effective approaches, a combination of

615 public and private decision-making around the construction and retrofitting of sidewalks and

616 driveways, backyards and front lawns would have to be represented, in turn motivated by

617 different preferences towards the various individual and neighborhood-level benefits and costs of

618 green infrastructure. Research is ongoing to include these and other new features in future

619 versions of L-GrID. 


\section{References}

Akan, A. O. (1993). Urban Stormwater Hydrology: A Guide to Engineering Calculations. : CRC Press.

Albrecht, K., \& Cartwright, K. (1989). Infiltration and hydraulic conductivity of a compacted earthen liner. Ground Water, 27(1), 14-19.

Angel, J. (1989). Bulletin 70 - Frequency Distributions of Heavy Rainstorms in Illinois: Illinois State Water Survey. Retrieved November, 18, 2014, from http://www.isws.illinois.edu/atmos/statecli/RF/download.htm

Atchison, D., \& Severson, L. (2004). RECARGA User's Manual, Version 2.3. University of Wisconsin - Madison. Civil \& Environmental Engineering Department, Water Resources Group. Retrieved October 3, 2011, from http://dnr.wi.gov/topic/stormwater/documents/InfStdsTools/RECARGA23User_Manual.pdf

Athayde, D. N., Shelly, P. E., Driscoll, E. D., Gaboury, D., \& Boyd, G. (1983). Results of the nationwide urban runoff program: Volume 1-Final report. United States Environmental Protection Agency, Water Planning Division.

Bingner, R., Theurer, F., \& Yuan, Y. (2010). AnnAGNPS Technical Processes: United States Department of Agriculture. Retrieved October 2, 2011, from http://www.nrcs.usda.gov/wps/portal/nrcs/detailfull/national/water/quality/?\&cid=stelprd b1043591

Bonebrake, T. C., \& Mastrandrea, M. D. (2010). Tolerance adaptation and precipitation changes complicate latitudinal patterns of climate change impacts. Proceedings of the National Academy of Sciences, 107(28), 12581-12586.

California Department of Transportation. (2009). Biofiltration Swale Design Guidance. Retrieved December 3, 2014, from http://www.dot.ca.gov/hq/LandArch/ec/stormwater/guidance/DG-BioSwale-Final02011309.pdf.

Caraco, D. (2011). Watershed Treatment Model. Retrieved October 27, 2010, from http://www.cwp.org/documents/cat_view/83-watershed-treatment-model.html

Carr, R., Esposito, C., \& Walesh, S. (2001). Street-surface storage for control of combined sewer surcharge. Journal of Water Resources Planning and Management, 10.1061/(ASCE)0733-9496(2001)127:3(162), 162-167.

Center for Neighborhood Technology. (2010). Green Values Stormwater Calculator. Retrieved October 27, 2010, from http://logan.cnt.org/calculator/calculator.php

City of Chicago. (2007). Street and Site Plan Design Standards. Retrieved October 30, 2011, from http://www.cityofchicago.org/content/dam/city/depts/cdot/StreetandSitePlanDesignStand ards407.pdf

City of Dallas. (1993). Drainage Design Manual. Retrieved December 3, 2014, from http://www.dallascityhall.com/public_works/pdf/DrainageDesignManual-searchable.pdf

Cook, E., \& Iverson, L. (2000). Urban forest cover of the Chicago region and its relation to household density and income. Urban Ecosystems, 4(2), 105-124. 
Finkenbine, J. K., Atwater, J. W., \& Mavinic, D. S. (2000). Stream health after urbanization. Journal of the American Water Resources Association, 36(5), 1149-1160.

Gonzalez-Meler, M. A., Cotner, L. A., Massey, D. A., Zellner, M. L., \& Minor, E. S. (2013). The Environmental and Ecological Benefits of Green Infrastructure for Stormwater Runoff in Urban Areas. JSM Environmental Science and Ecology, 1(2), 1007.

Green, W. H., \& Ampt, G. (1911). Studies on soil physics, part I - flow of air and water through soils. Journal of Agricultural Science, 4, 1-24.

Hatt, B. E., Deletic, A., \& Fletcher, T. D. (2007). Stormwater reuse: designing biofiltration systems for reliable treatment. Water Science and Technology, 55(4), 201-209.

Hatt, E. H., Fletcher, F. D., \& Deletic, A. (2009). Hydrologic and pollutant removal performance of stormwater biofiltration systems at the field scale. Journal of Hydrology, 365(3-4), 310-321.

Hayhoe, K., \& Wuebbles, D. (2008). Chicago Climate Action Plan. Chicago, IL. Retrieved July 14, 2010, from http://www.chicagoclimateaction.org/pages/research__reports/8.php

Hood, M. J., Clausen, J. C., \& Warner, G. S. (2007). Comparison of stormwater lag times for low impact and traditional residential development. Journal of the American Water Resources Association, 43(4), 1036-1046.

Huff, F., \& Angel, J. (1992). Rainfall History Atlas of the Midwest: Midwestern Climate Center, National Oceanic and Atmospheric Administration. Retrieved November 30, 2011, from http://www.isws.illinois.edu/pubdoc/B/ISWSB-71.pdf

Hunt, W. F., \& Lord, W. G. (2006). Urban Waterways: Bioretention performance, design, construction, and maintenance. North Carolina State University, North Carolina Cooperative Extension Service. Retrieved November 29, 2011 from https://www.bae.ncsu.edu/extension/ext-publications/water/protecting/ag-588-05bioretention-performance-design-construction-maintenance.pdf

Illinois State Climatologist Office. (2008). Monthly Pan Evaporation for Chicago Botanical Gardens, Glencoe, IL (site 11-1497). Retrieved November 30, 2011, from http://www.isws.illinois.edu/atmos/statecli/Pan-Evap/panevapx.htm

Illinois State Geological Survey. (2011). Lowest and Highest Points in Cook County. Retrieved November 28, 2011, from http://www.isgs.uiuc.edu/education/hi-low/cook.shtml

Jaffe, M., Zellner, M., Minor, E., Gonzalez-Meler, M., Cotner, L. B., Massey, D., Ahmed, H., Elberts, M., Wise, S., Sprague, H., Miller, B. (2010). The Illinois Green Infrastructure Study. A Report to the Illinois Environmental Protection Agency on Criteria in Section 15 of Public Act 96-0026, the Illinois Green Infrastructure for Clean Water Act of 2009. Chicago, IL.

Krumm, R., Nelson, D., \& Beaverson, S. (1984). Master Data Set for Illinois Soil Associations Map (500K).

Larson, R. A., \& Safferman, S. I. (2008). Storm water best management practices that maximize aquifer recharge. Journal of Green Building, 3(1), 126 - 138.

Lazzarin, R. M., Castellotti, F., \& Busato, F. (2005). Experimental measurements and numerical modelling of a green roof. Energy and Buildings, 37(12), 1260-1267.

Lee, J. G., Selvakumar, A., Alvi, K., Riverson, J., Zhen, J. X., Shoemaker, L., \& Lai, F.-h. (2012). A watershed-scale design optimization model for stormwater best management practices. Environmental Modelling \& Software, 37(November 2012), 6-18. 
Li, H., Sharkey, L. J., Hunt, W. F., \& Davis, A. P. (2009). Mitigation of Impervious Surface Hydrology Using Bioretention in North Carolina and Maryland. Journal of Hydrologic Engineering, 10.1061/(ASCE)1084-0699(2009)14:4(407), 407-415.

Martin-Mikle, C. J., de Beursa, K. M., Julian, J. P., \& Mayerc, P. M. (2015). Identifying priority sites for low impact development (LID) in a mixed-use watershed. Landscape and Urban Planning, 140, 29-41.

Metropolitan Water Reclamation District of Greater Chicago. (2014). Stickney Water Reclamation Plant. Retrieved November 18, 2014, from https://www.mwrd.org/pv_obj_cache/pv_obj_id_E52F7E1A7E8A2B3F9FA1A36D2BB7 073431054B00/filename/SWRP\%20full\%20document.pdf

Midwest Spatial Decision Support Systems (MSDSS) Partnership. (2010). Impacts of Land Use Change on Water Resources. Retrieved August 19, 2011, from https://engineering.purdue.edu/ lthia/

Montalto, F. C., Behr, C., Alfredo, K., Wolf, M., Arye, M., \& Walsh, M. (2007). Rapid assessment of the cost-effectiveness of low impact development for CSO control. Landscape and Urban Planning, 82(3), 117-131.

Morrow, W. S., \& Sharpe, J. B. (2009). Preliminary Assessment of the Potential for Inducing Stormwater Infiltration in Cook County, Illinois: US Geological Survey. Retrieved August 14, 2014, from http://pubs.usgs.gov/of/2009/1212/pdf/ofr2009-1212.pdf

National Oceanic and Atmospheric Administration. (2014). Precipitation Frequency Data Server. Retrieved September 3, 2014, from http://dipper.nws.noaa.gov/hdsc/pfds/

Nelson, E. J., \& Booth, D. B. (2002). Sediment sources in an urbanizing, mixed land-use watershed. Journal of Hydrology, 264(1-4), 51-68.

Oram, B. (N.d.). Estimation of Green-Ampt Infiltration Parameters. Retrieved October 27, 2010, from http://www.water-research.net/Waterlibrary/Stormwater/greenamp.pdf

Partnership for Water Sustainability in British Columbia. (2013). Water Balance Model. Retrieved January 20, 2013, from http://waterbalance.ca/

PV and Associates. (2013). WinSLAMM (Version 10.0). Retrieved January 28, 2013, from http://winslamm.com/

Rossman, L. (2010). 2010. Storm Water Management Model. Users’ Manual. Version5.0.: U.S. Department of Environmental Protection, Water Supply and Water Resources Division, National Risk Management Research Laboratory. Retrieved October 3, 2011, from http://eng.odu.edu/cee/resources/model/mbin/swmm/win/epaswmm5_manual.pdf

Shoemaker, L. (2009). SUSTAIN: a framework for placement of best management practices in urban watersheds to protect water quality. Retrieved January 30, 2013, from http://www.epa.gov/nrmrl/wswrd/wq/models/sustain/

Tetra Tech. (2006). Spreadsheet Tool for Estimating Pollutant Load (STEPL) (Version 4). Retrieved January 28, 2013, from https://wiki.epa.gov/watershed2/index.php/Spreadsheet_Tool_for_Estimating_Pollutant_ Load_\%28STEPL\%29

United States Department of Agriculture. (1986). Urban Hydrology for Small Watersheds. TR55.: Natural Resources Conservation Service, Conservation Engineering Division.

United States Department of Agriculture. (2006). Manning's Equation. Retrieved September 20, 2010, from http://www.stream.fs.fed.us/fishxing/help/8_Hydraulic_Reference/Manning_s_Equation. htm 
United States Environmental Protection Agency. (1999). Storm WaterTechnology Fact Sheet Bioretention. Retrieved June 4, 2014, from http://water.epa.gov/scitech/wastetech/upload/2002_06_28_mtb_biortn.pdf

United States Environmental Protection Agency. (2000). Low impact development (LID): A literature review.

Urbonas, B. R. (1999). Design of a Sand Filter for Stormwater Quality Enhancement. Water Environment Research, 71(1), 102-113.

Volesky, B., \& Hola, Z. R. (1995). Biosorption of heavy metals. Biotechnology Progress 11(3), 235-250.

Vought, L. B. M., Dahl, J., Pedersen, C. L., \& Lacoursière, J. O. (1994). Nutrient retention in riparian ecotones. Ambio, 23(6), 342-348.

Walker, W. (2007). P8 Urban Catchment Model. Retrieved October 27, 2010, from http://www.wwwalker.net/p8/

Wilensky, U. (1999). NetLogo [Computer software]. Center for Connected Learning and Computer-Based Modeling, Northwestern University, Evanston, IL. Retrieved from http://ccl.northwestern.edu/netlogo/

Yang, Y., Endreny, T. A., \& Nowak, D. J. (2015). Simulating the effect of flow path roughness to examine how green infrastructure restores urban runoff timing and magnitude. Urban Forestry \& Urban Greening, 14(2), 361-367.

Yen, B. C., \& Chow, V. T. (1980). Design hyetographs for small drainage structures. Journal of the Hydraulics Division ASCE, 106(HY6), 1055-1075 


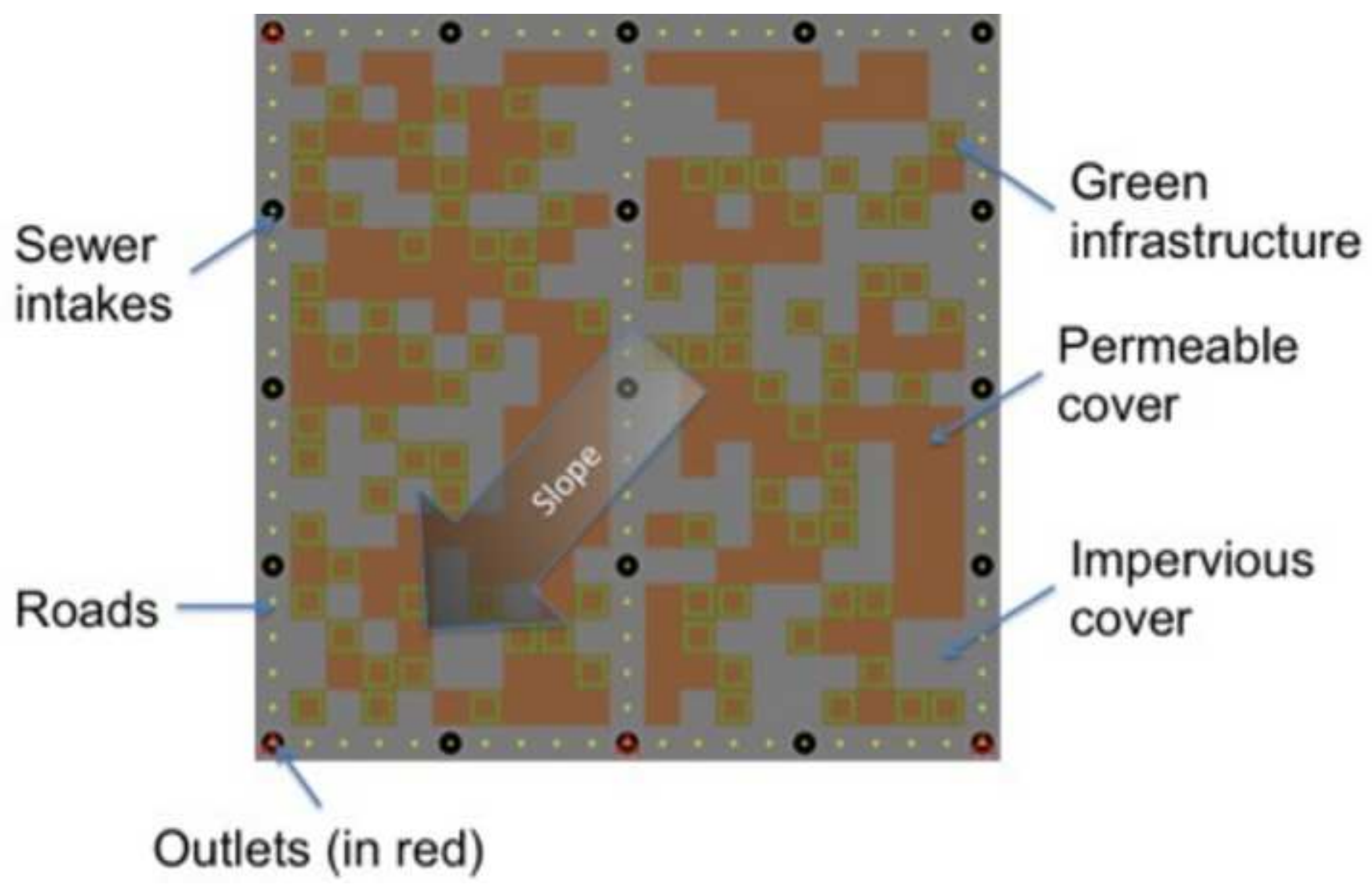

Green infrastructure

Permeable cover

Impervious cover

\section{Outlets (in red)}




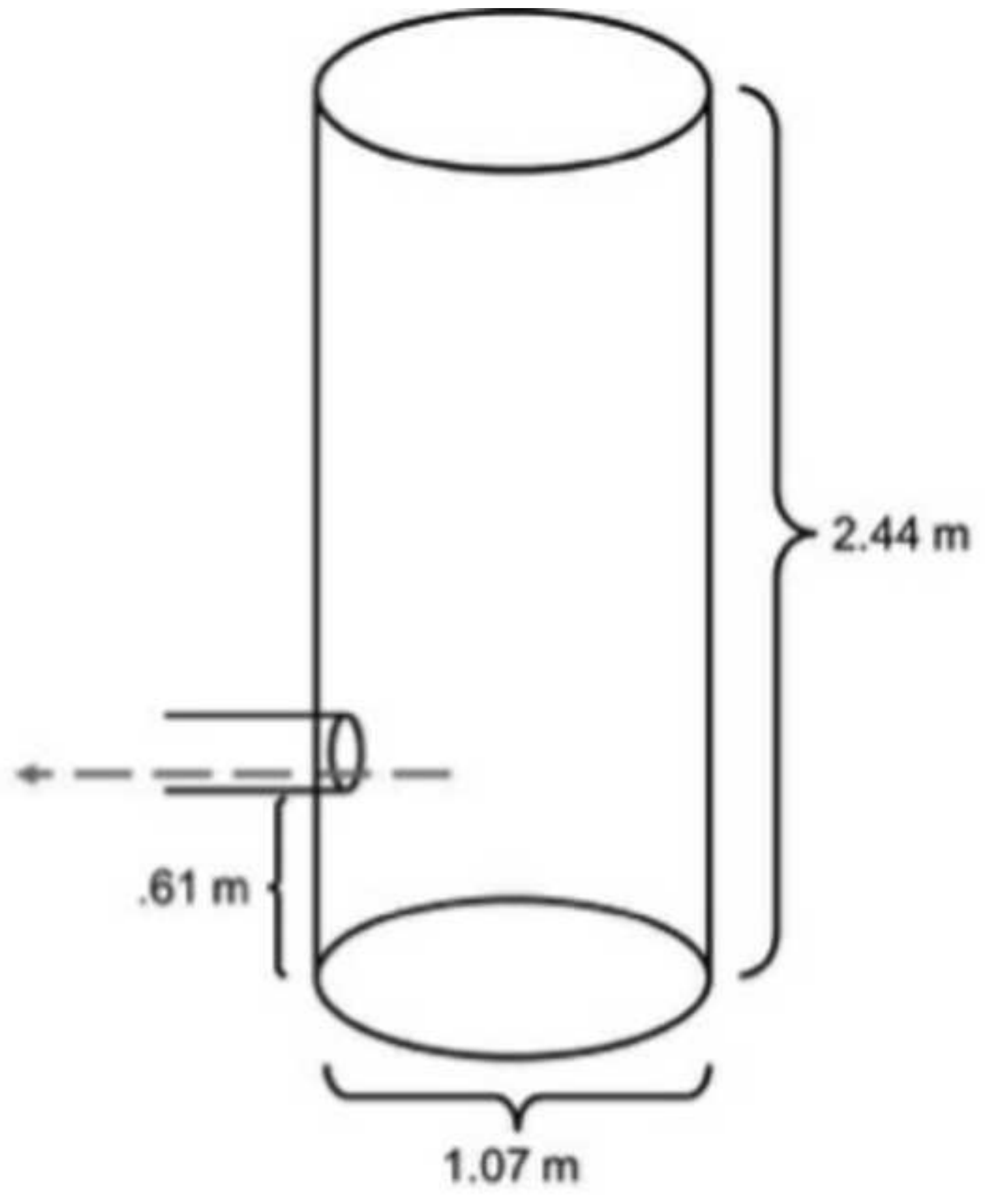

Figure 2: Sewer intake assumptions in L-GrID.

Figure 2: Sewer intake assumptions in L-GrID.

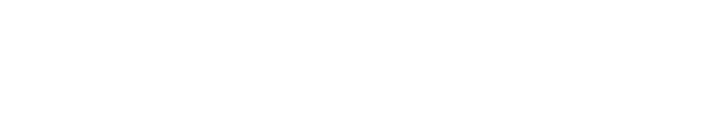


Figure 3: Processes and order of events in L-GrID.
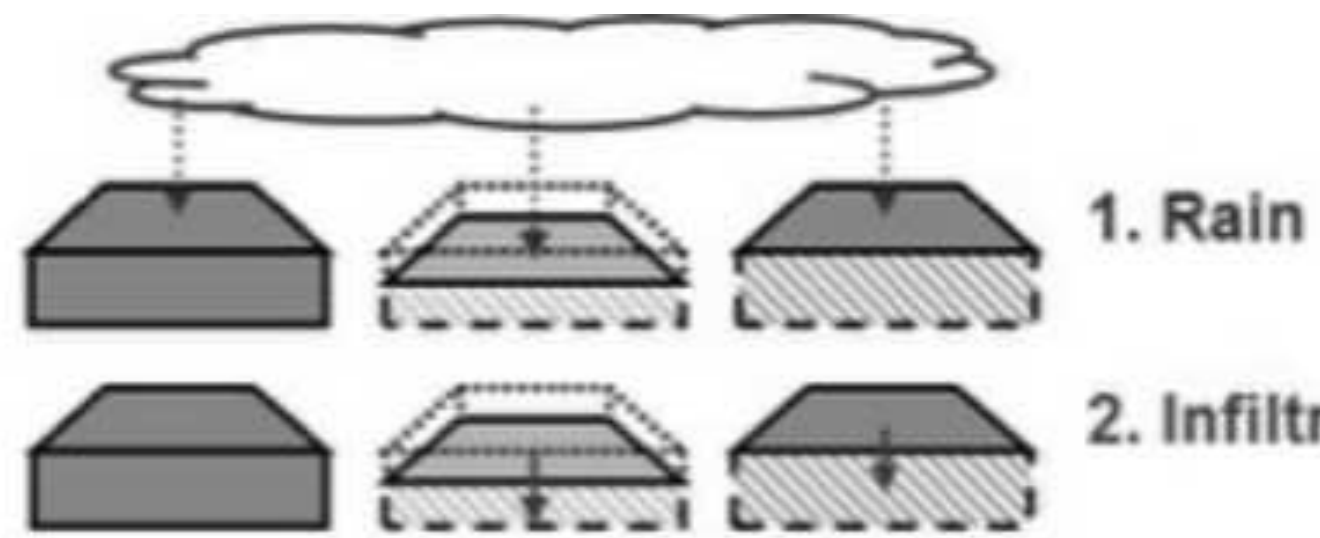

2. Infiltration
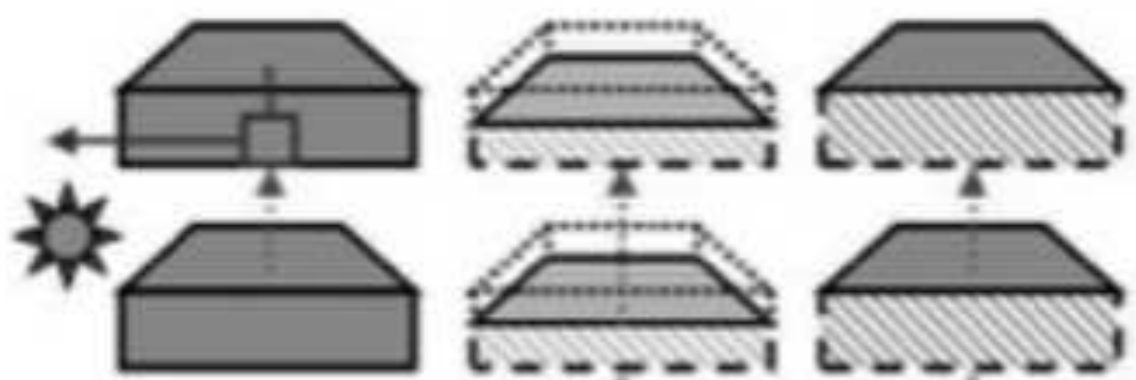

3. Sewers

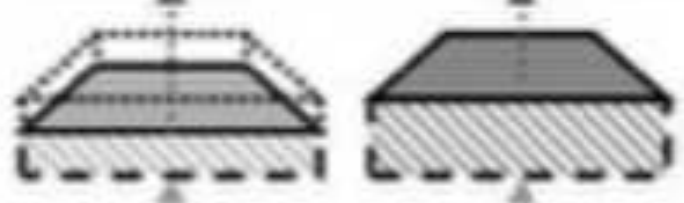

4. Evaporation
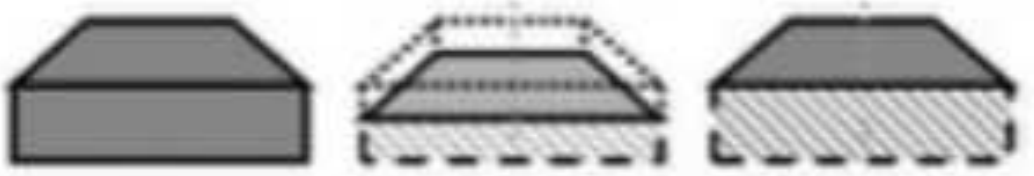

5. Evapotranspiration
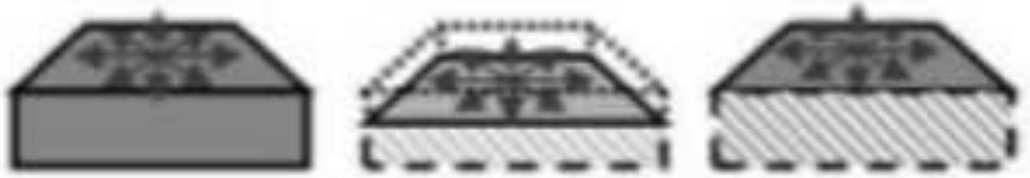

6. Surface Flow
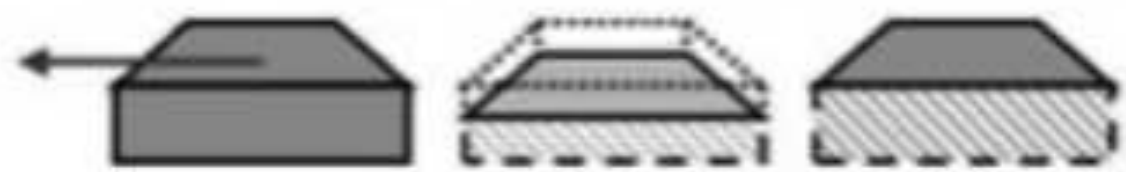

7. Outflow (one cell only)

$$
\begin{gathered}
\text { Impervious Green Permeable } \\
\text { Infrastructure }
\end{gathered}
$$




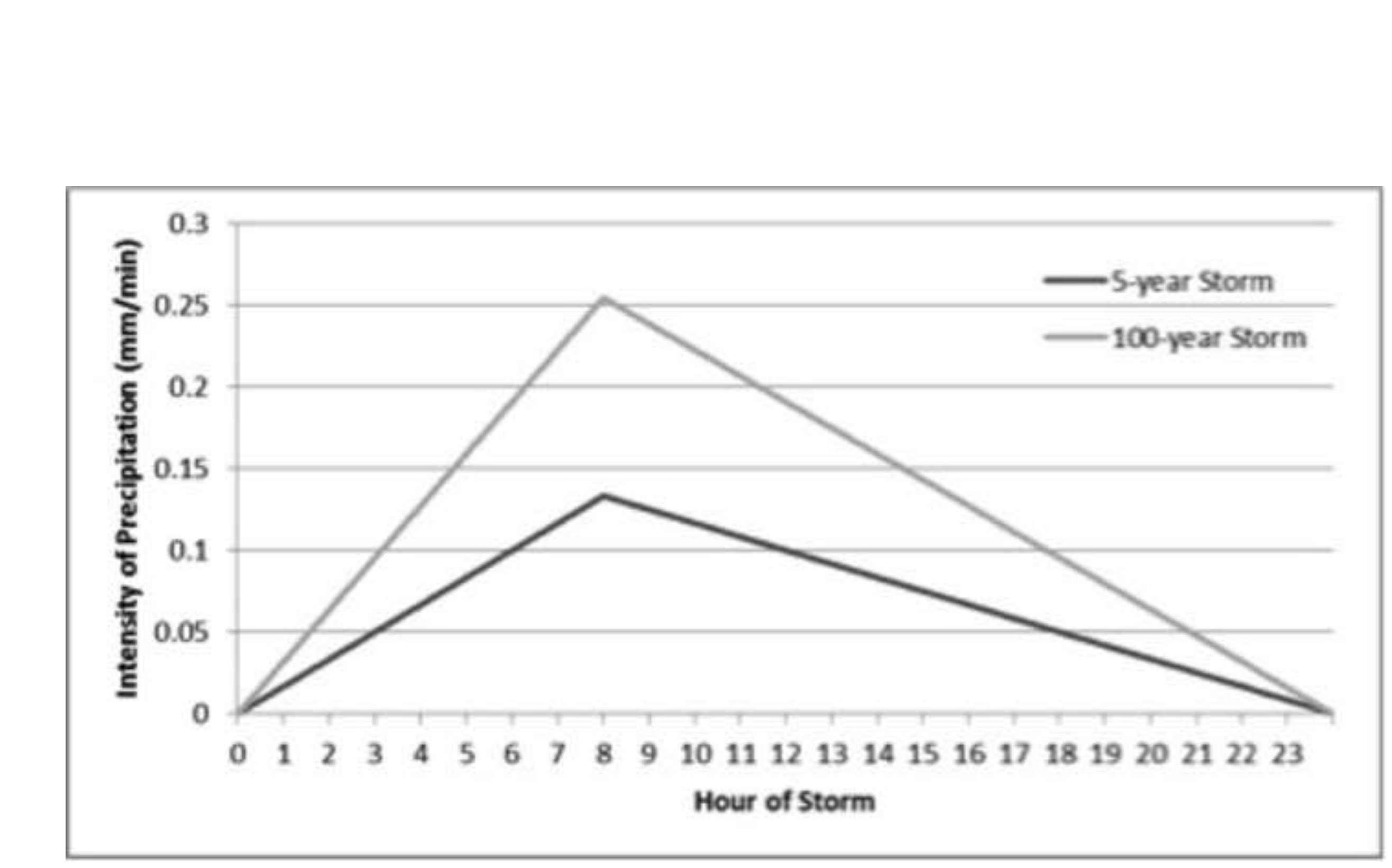

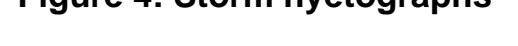
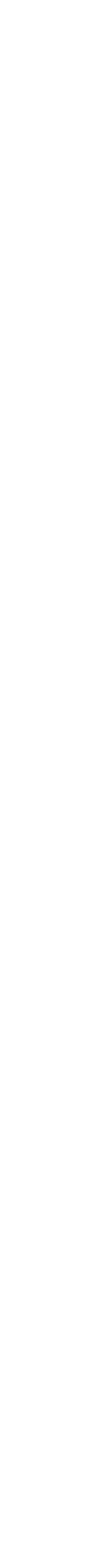
. .
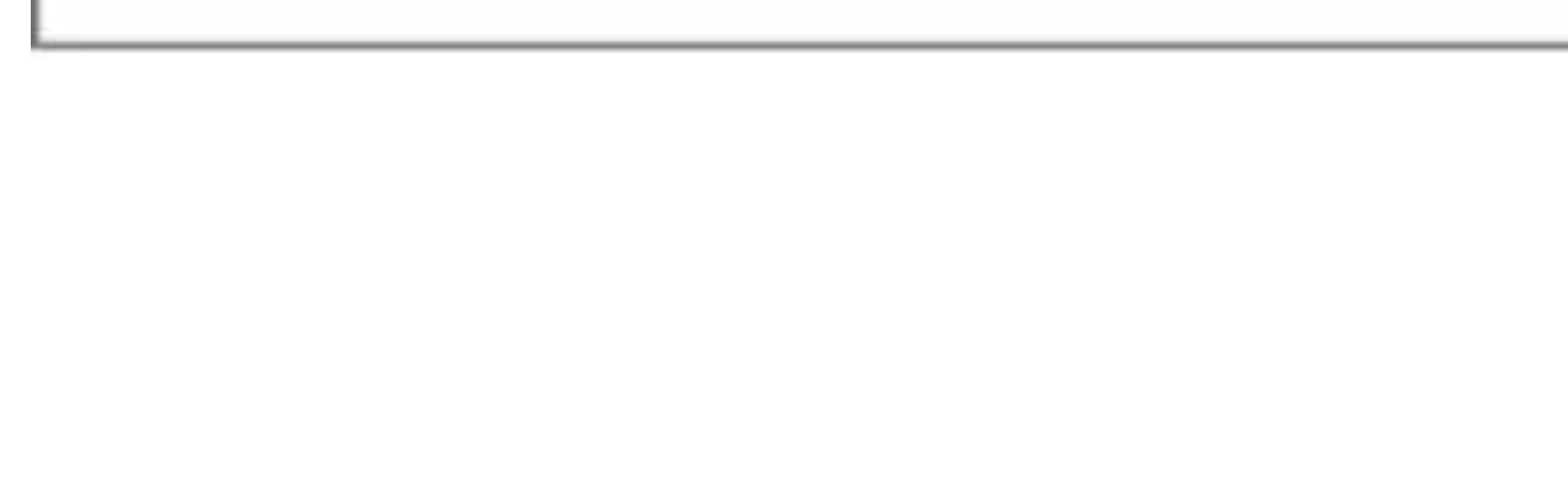


\section{5-year storms}
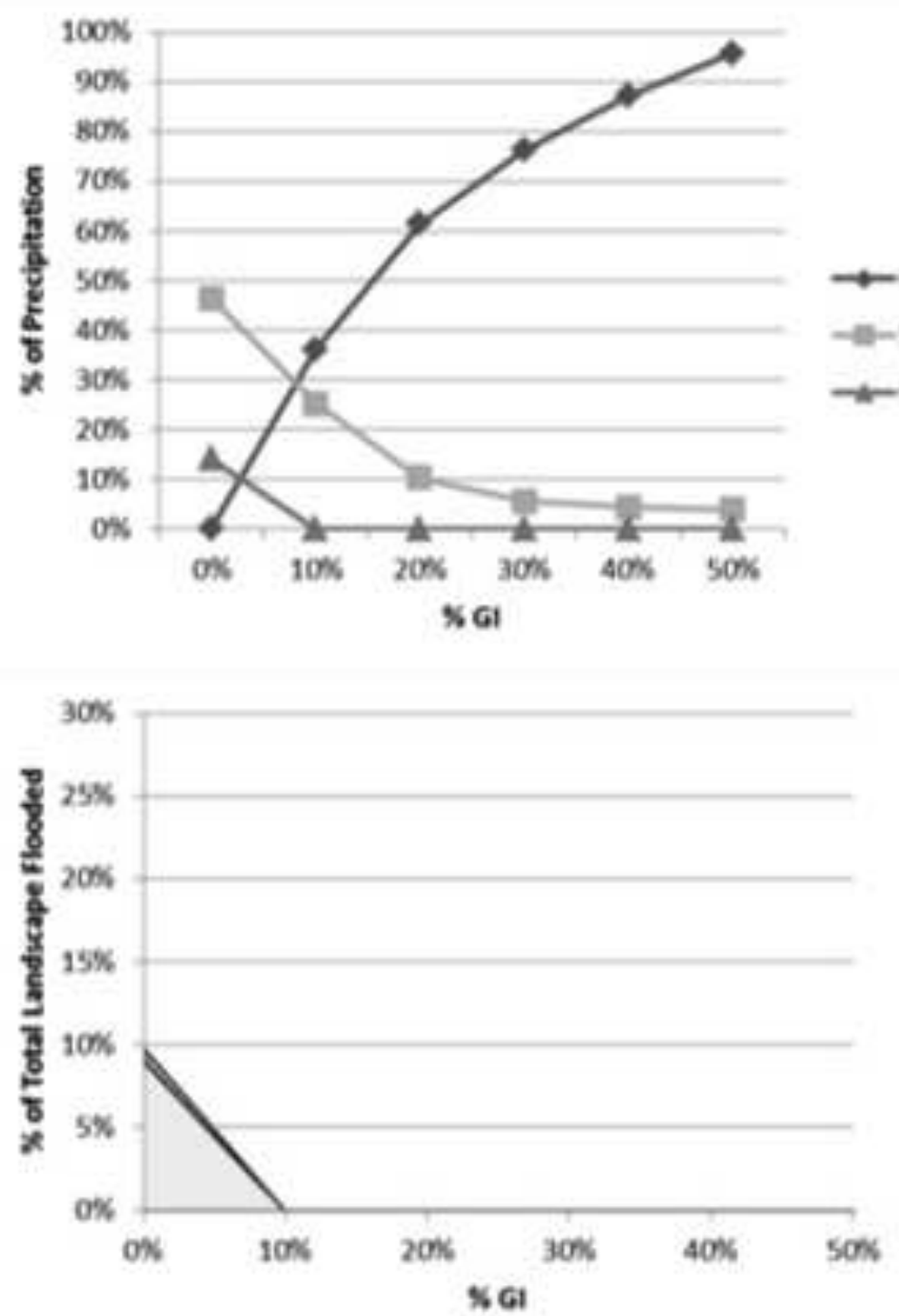

100-year storms
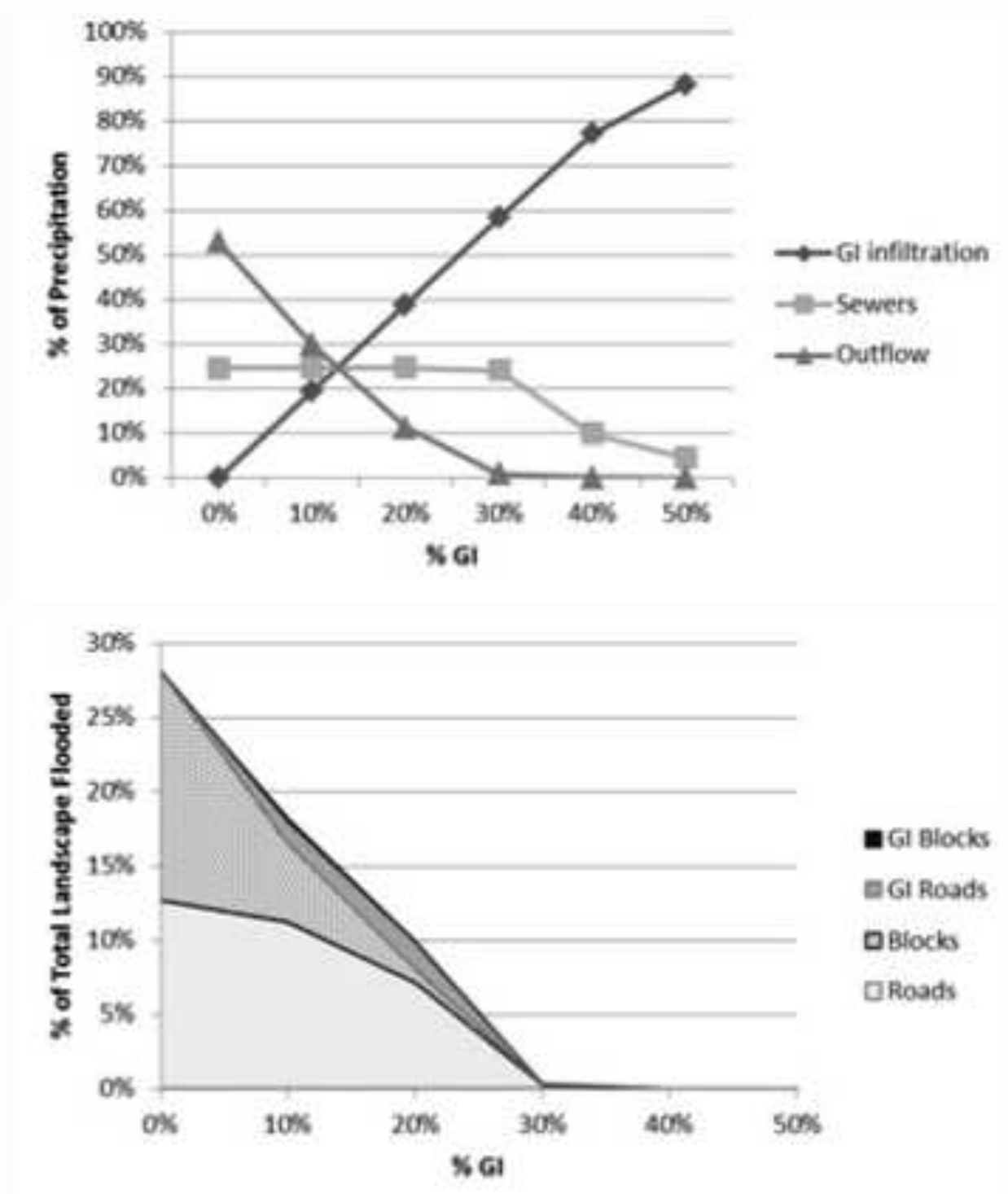

a Glocis nal Rosds ablodes

araads
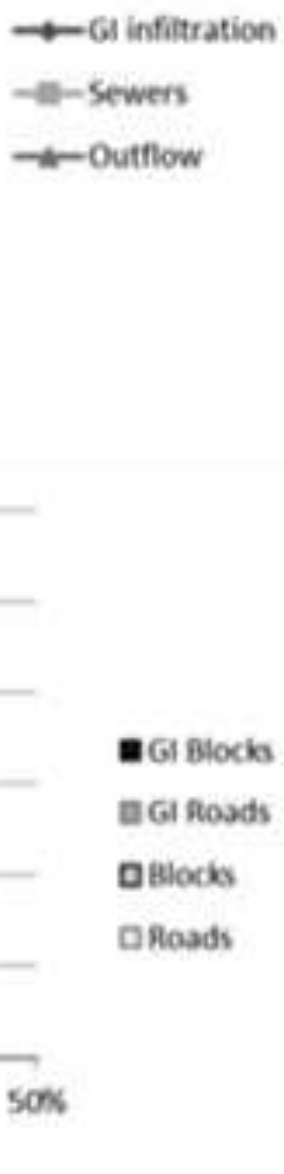
(a)

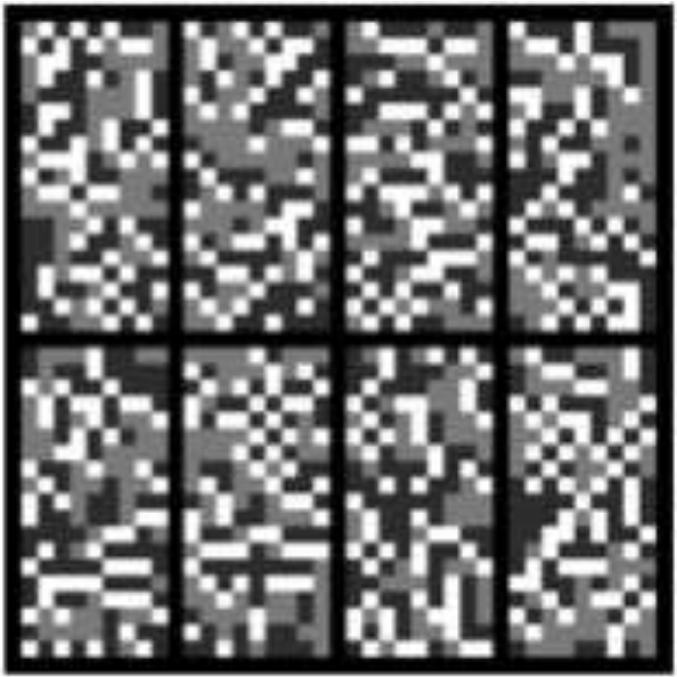

(d)

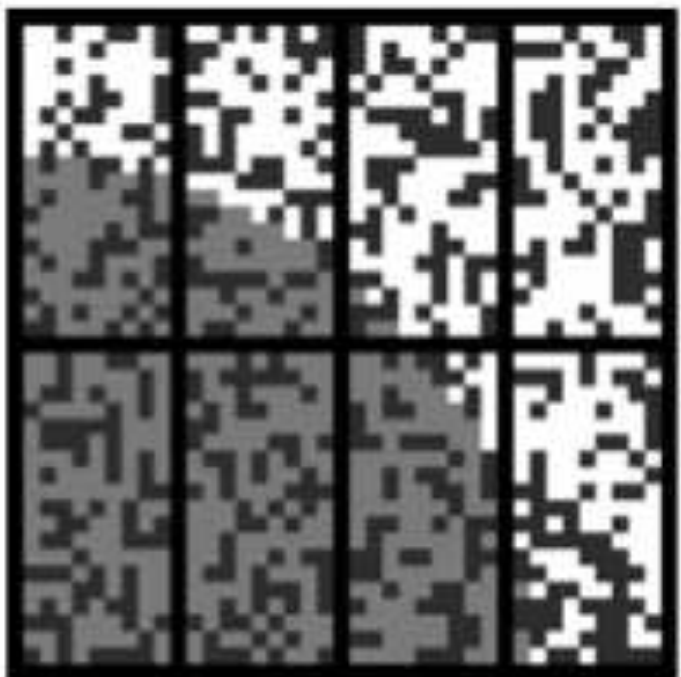

(b)

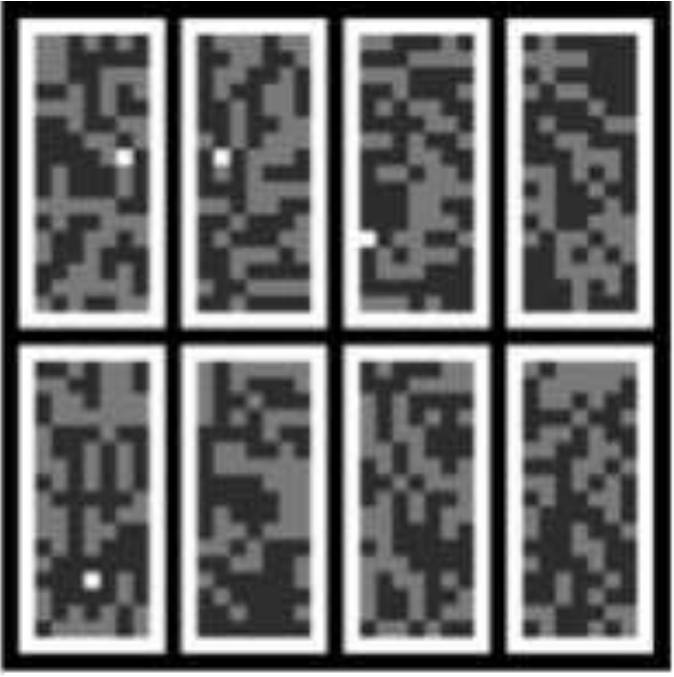

(c)

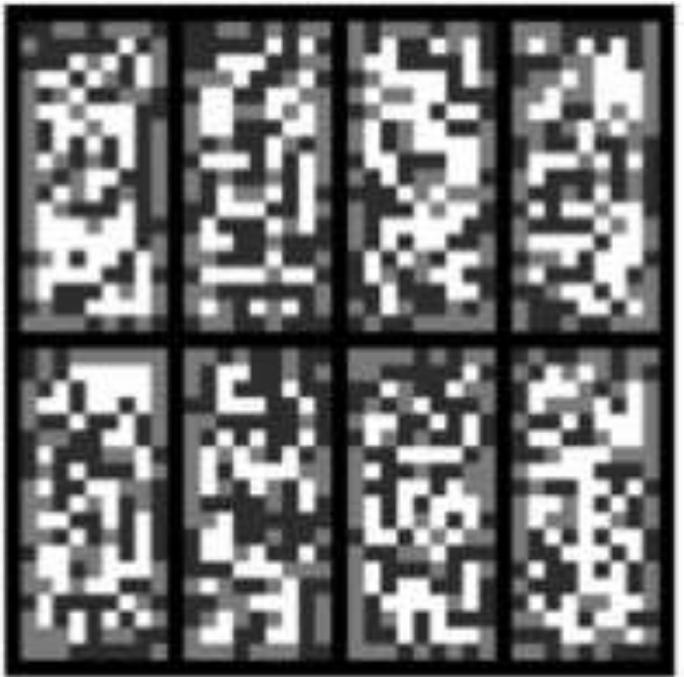

(e)

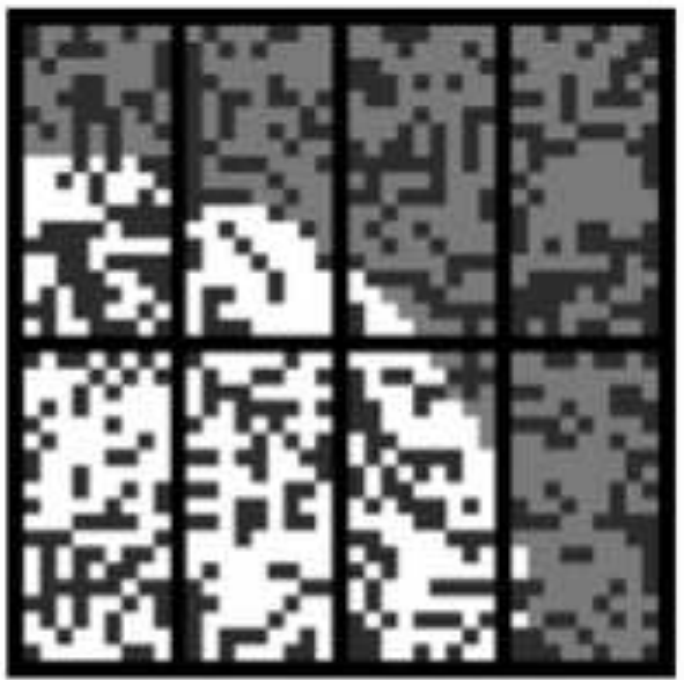

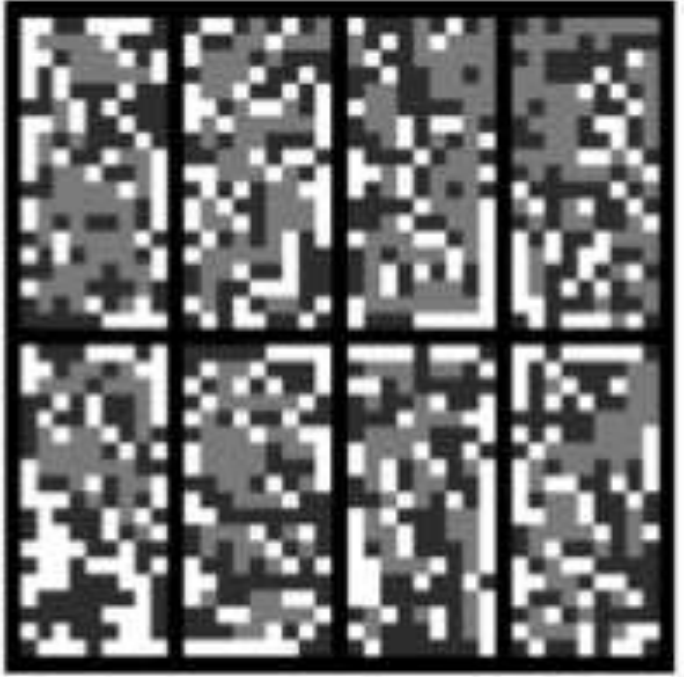

= road

$\square$ = impermeable block = permeable block = green infrastructure 

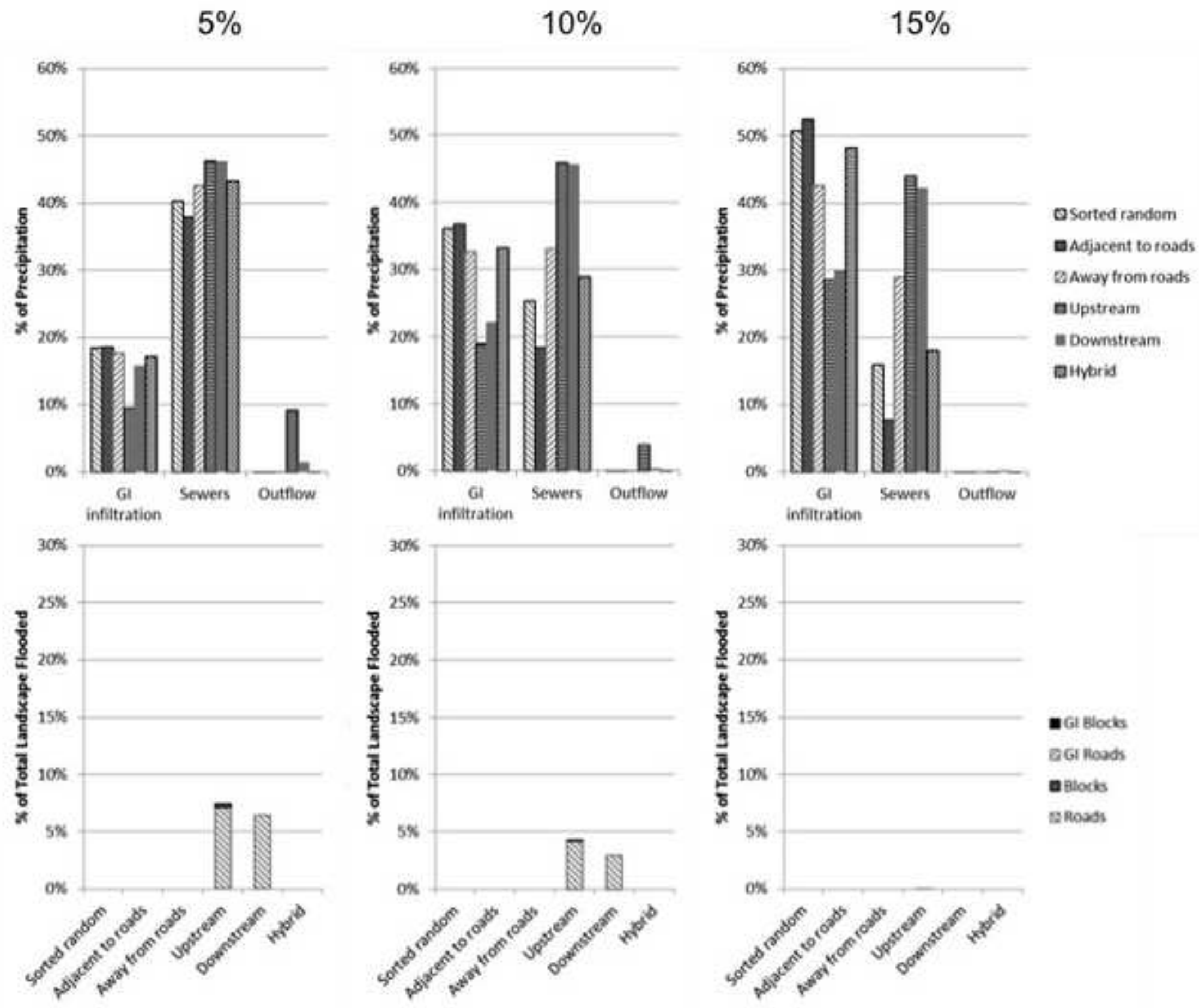
$15 \%$

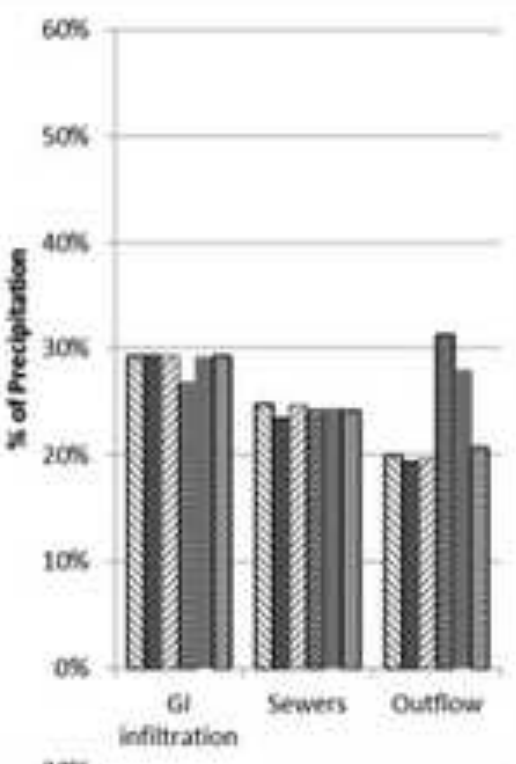

305
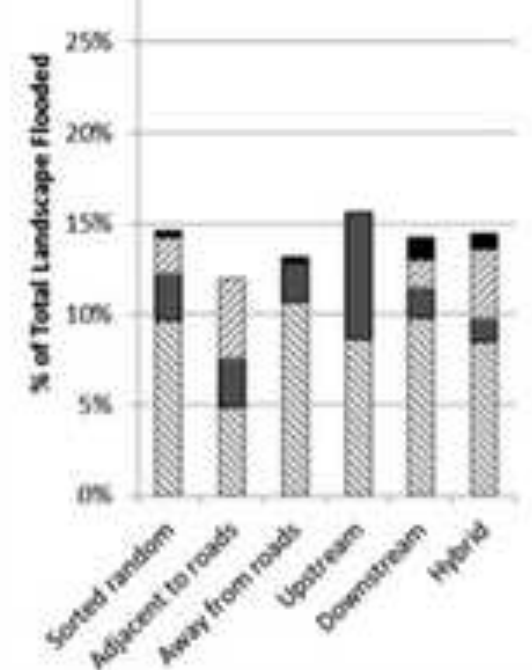

$20 \%$

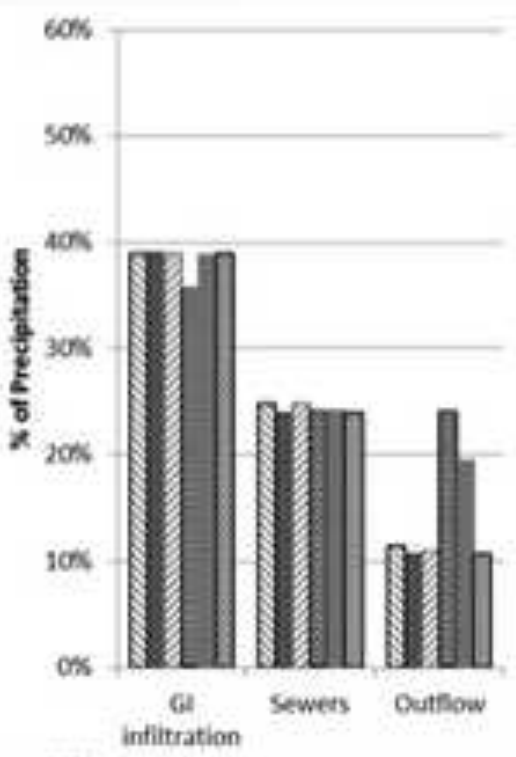

300

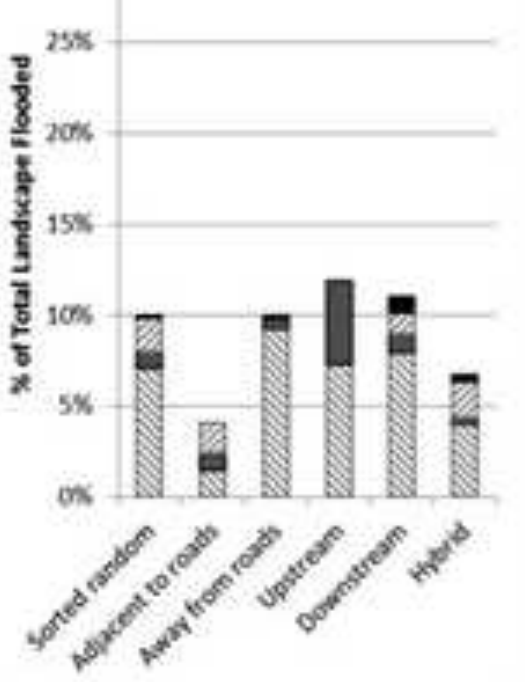

$25 \%$
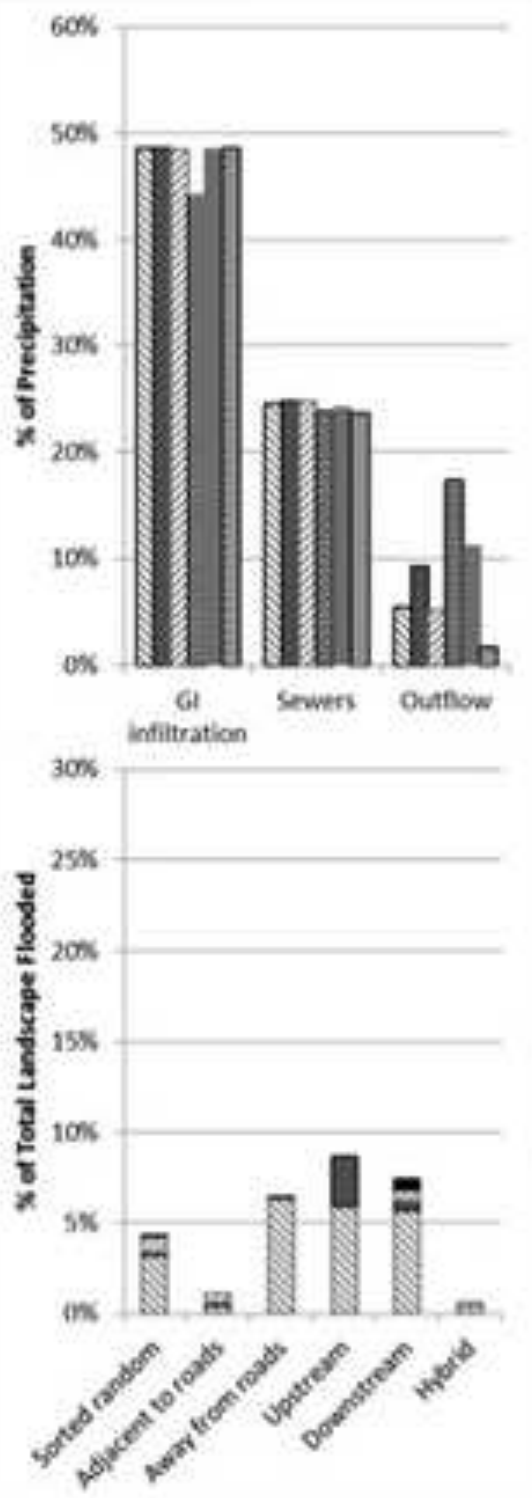

$30 \%$

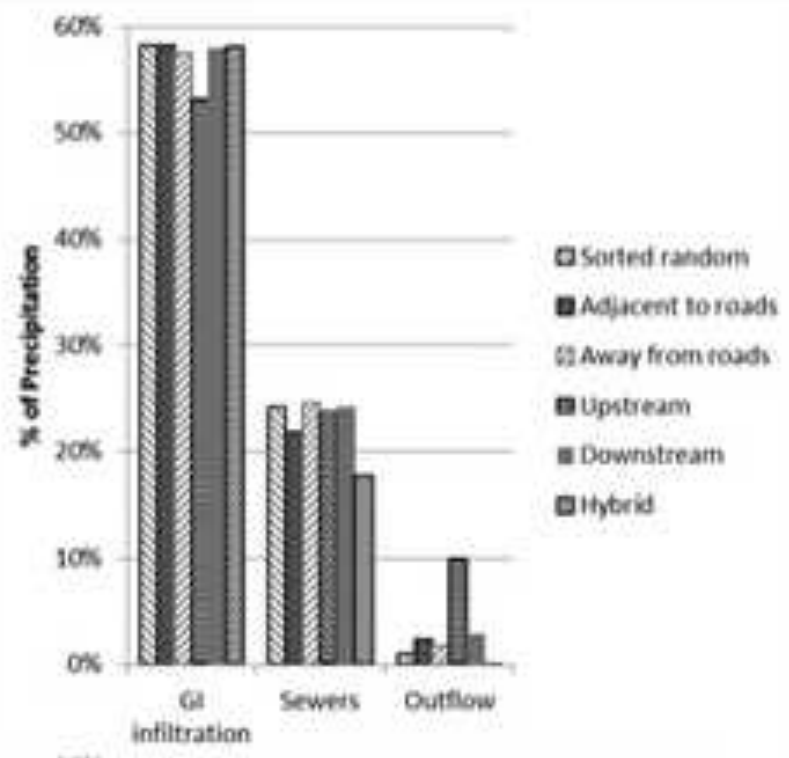

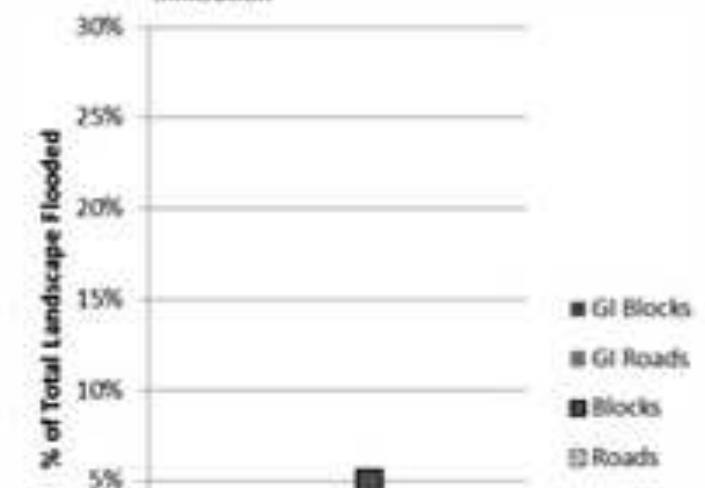

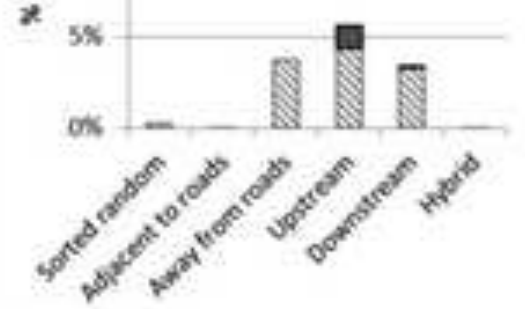


Table 1: Summary of existing stormwater runoff models.

\begin{tabular}{|c|c|c|c|c|c|c|c|c|}
\hline Model & Type & Purpose & $\begin{array}{l}\text { Data and } \\
\text { time needs }\end{array}$ & Inputs & Outputs & Time steps & Scale & Spatially Explicit \\
\hline $\begin{array}{l}\text { Watershed } \\
\text { Treatment } \\
\text { Model } \\
\text { (WTW) }\end{array}$ & Spreadsheet & $\begin{array}{l}\text { Calculate runoff, } \\
\text { apply future } \\
\text { practices, } \\
\text { estimate impact } \\
\text { of future growth }\end{array}$ & Low & $\begin{array}{l}\text { Land use, annual } \\
\text { precipitation, soil } \\
\text { types }\end{array}$ & Estimated runoff & N.A. & User defined & No \\
\hline STEPL & Spreadsheet & $\begin{array}{l}\text { Calculate } \\
\text { nutrient and } \\
\text { sediment loads } \\
\text { from different } \\
\text { land uses and the } \\
\text { load reductions } \\
\text { from BMPs }\end{array}$ & Low & $\begin{array}{l}\text { Land uses, } \\
\text { animals, } \\
\text { pricipitation, } \\
\text { irrigation, soil } \\
\text { data, septic } \\
\text { systems, other } \\
\text { discharge }\end{array}$ & $\begin{array}{l}\text { Annual nutrient } \\
\text { and sediment } \\
\text { loads, load } \\
\text { reduction }\end{array}$ & N.A. & $\begin{array}{l}\text { Watershed, but } \\
\text { could be } \\
\text { smaller }\end{array}$ & No \\
\hline TR-55 & Worksheet & $\begin{array}{l}\text { Prediction of } \\
\text { changes in runoff }\end{array}$ & Low & $\begin{array}{l}\text { Land use, soil } \\
\text { type, rainfall }\end{array}$ & $\begin{array}{l}\text { Runoff volume, } \\
\text { peak rate of } \\
\text { discharge, storage } \\
\text { volumes, } \\
\text { hydrographs }\end{array}$ & N.A. & $\begin{array}{l}\text { Urban } \\
\text { watersheds } \\
\text { smaller than } \\
2,000 \text { acres }\end{array}$ & $\begin{array}{l}\text { No, uses SCS } \\
\text { curve numbers to } \\
\text { estimate runoff }\end{array}$ \\
\hline L-THIA & $\begin{array}{l}\text { Web-based } \\
\text { program }\end{array}$ & $\begin{array}{l}\text { Prediction of } \\
\text { changes in runoff }\end{array}$ & Low & $\begin{array}{l}\text { Geographic } \\
\text { location, land use, } \\
\text { soil type, acreage, } \\
\text { type of land use } \\
\text { changes taking } \\
\text { place }\end{array}$ & $\begin{array}{l}\text { Annual runoff } \\
\text { volumes and } \\
\text { depths, pollutant } \\
\text { loading }\end{array}$ & N.A. & $\begin{array}{l}\text { Small to large } \\
\text { watersheds }\end{array}$ & $\begin{array}{l}\text { No, uses } \\
\text { historical data for } \\
\text { the Midwest and } \\
\text { TR-55 curve } \\
\text { numbers to } \\
\text { estimate runoff }\end{array}$ \\
\hline $\begin{array}{l}\text { Green Values } \\
\text { Calculataor }\end{array}$ & $\begin{array}{l}\text { Web-based } \\
\text { program }\end{array}$ & $\begin{array}{l}\text { Prediction of } \\
\text { relative impacts } \\
\text { of alternative } \\
\text { BMP projects }\end{array}$ & Low & $\begin{array}{l}\text { General site } \\
\text { specific data (e.g. } \\
\text { number of lots, } \\
\text { sidewalk width), } \\
\text { soil type, } \\
\text { precipitation, land } \\
\text { cover, BMPs }\end{array}$ & $\begin{array}{l}\text { Discharge, } \\
\text { groundwater } \\
\text { recharge, cost } \\
\text { benefit analysis }\end{array}$ & N.A. & Site specific & $\begin{array}{l}\text { No, uses TR-55 to } \\
\text { estimate outcomes }\end{array}$ \\
\hline
\end{tabular}




\begin{tabular}{|c|c|c|c|c|c|c|c|c|}
\hline $\begin{array}{l}\text { Water } \\
\text { Balance } \\
\text { Model (BC) }\end{array}$ & $\begin{array}{l}\text { Web-based } \\
\text { tool requiring } \\
\text { paid } \\
\text { subscription }\end{array}$ & $\begin{array}{l}\text { Planning water } \\
\text { quality }\end{array}$ & Moderate & $\begin{array}{l}\text { Drainage area, } \\
\text { elevation, slope, } \\
\text { soil types, land } \\
\text { uses, surface } \\
\text { conditions, } \\
\text { network of } \\
\text { surface } \\
\text { enhancements for } \\
\text { managing runoff }\end{array}$ & $\begin{array}{l}\text { Runoff, nutrient } \\
\text { loading, other } \\
\text { biological data }\end{array}$ & Hourly & $\begin{array}{l}\text { Sites, } \\
\text { developments, } \\
\text { or entire } \\
\text { watersheds }\end{array}$ & $\begin{array}{l}\text { Runoff volumes } \\
\text { are aggregated per } \\
\text { subcatchment. }\end{array}$ \\
\hline RECARGA & $\begin{array}{l}\text { Stand-alone } \\
\text { program }\end{array}$ & $\begin{array}{l}\text { Sizing of } \\
\text { bioretention and } \\
\text { bioinfiltration } \\
\text { facilities for new } \\
\text { developments }\end{array}$ & Moderate & $\begin{array}{l}\text { Precipitation, soil } \\
\text { type, land use, } \\
\text { and cover } \\
\text { properties }\end{array}$ & $\begin{array}{l}\text { Sizing of BMPs } \\
\text { to meet goals for } \\
\text { infiltrarion and } \\
\text { runoff rates }\end{array}$ & 15 minutes & $\begin{array}{l}\text { Small urban } \\
\text { watersheds }\end{array}$ & $\begin{array}{l}\text { No, uses TR-55 to } \\
\text { estimate runoff } \\
\text { into BMPs before } \\
\text { routing through } \\
\text { other processes }\end{array}$ \\
\hline P8 & $\begin{array}{l}\text { Stand-alone } \\
\text { program }\end{array}$ & $\begin{array}{l}\text { Evaluating } \\
\text { development } \\
\text { proposals to } \\
\text { select and size } \\
\text { BMPs in } \\
\text { treatment chains }\end{array}$ & $\begin{array}{l}\text { High } \\
\text { (substantial } \\
\text { calibration) }\end{array}$ & $\begin{array}{l}\text { Weather data, } \\
\text { land area, land } \\
\text { cover, soil type, } \\
\text { SCS curve } \\
\text { number, BMP } \\
\text { values }\end{array}$ & $\begin{array}{l}\text { Estimated runoff } \\
\text { and water quality, } \\
\text { estimated change } \\
\text { in flow and water } \\
\text { quality }\end{array}$ & Hourly & $\begin{array}{l}\text { Multiple scales, } \\
\text { but more } \\
\text { appropriate for } \\
\text { development } \\
\text { scale }\end{array}$ & $\begin{array}{l}\text { Not for BMP } \\
\text { location, limited } \\
\text { capability in flow } \\
\text { and pollutant } \\
\text { routing, } \\
\text { watersheds are } \\
\text { divided into } \\
\text { pervious and } \\
\text { impervious zones }\end{array}$ \\
\hline AGNPS & $\begin{array}{l}\text { Stand-alone } \\
\text { program }\end{array}$ & $\begin{array}{l}\text { Predict } \\
\text { agricultural } \\
\text { runoff during } \\
\text { single events }\end{array}$ & High & $\begin{array}{l}\text { Soil tyle, slope, } \\
\text { fertilizer type } \\
\text { used }\end{array}$ & $\begin{array}{l}\text { Nutrients, } \\
\text { pesticides, } \\
\text { sediments }\end{array}$ & Daily & $\begin{array}{l}\text { Small to large } \\
\text { watersheds, up } \\
\text { to } 20,000 \\
\text { hectares }\end{array}$ & Yes \\
\hline WinSLAMM & $\begin{array}{l}\text { Stand-alone } \\
\text { program, } \\
\text { driven by } \\
\text { database not } \\
\text { formulas }\end{array}$ & $\begin{array}{l}\text { Assess } \\
\text { effectiveness of } \\
\text { BMPs in } \\
\text { reducing } \\
\text { pollutant } \\
\text { concentrations } \\
\text { during small and } \\
\text { medium storms }\end{array}$ & $\begin{array}{l}\text { High } \\
\text { (substantial } \\
\text { calibration) }\end{array}$ & $\begin{array}{l}\text { Drainage area, } \\
\text { land cover and } \\
\text { uses, sewersheds, } \\
\text { rainfall, runoff } \\
\text { coefficients, } \\
\text { sediment and } \\
\text { pollution } \\
\text { distribution }\end{array}$ & $\begin{array}{l}\text { Pollutant } \\
\text { concentrations, } \\
\text { runoff volumes, } \\
\text { hydrographs by } \\
\text { source area, land } \\
\text { use, or rainfall } \\
\text { event }\end{array}$ & $\begin{array}{l}\text { User- } \\
\text { defined, } \\
\text { unclear } \\
\text { range of } \\
\text { acceptabe } \\
\text { values }\end{array}$ & $\begin{array}{l}\text { Site to } \\
\text { watersheds }\end{array}$ & $\begin{array}{l}\text { Yes, for flow } \\
\text { routing }\end{array}$ \\
\hline
\end{tabular}




\begin{tabular}{|l|l|l|l|l|l|l|l|}
\hline SWMM & $\begin{array}{l}\text { Stand-alone } \\
\text { program, can be } \\
\text { supplemented } \\
\text { with extensions }\end{array}$ & $\begin{array}{l}\text { Design sewer } \\
\text { systems (and } \\
\text { BMPs) over } \\
\text { large scales }\end{array}$ & High & $\begin{array}{l}\text { Precipitation, land } \\
\text { covers, and a } \\
\text { subcatchment } \\
\text { drainage network }\end{array}$ & $\begin{array}{l}\text { Quantity and quality } \\
\text { of runoff for each } \\
\text { subcatchment, flow } \\
\text { rate and depth, and } \\
\text { quality of water in } \\
\text { drainage network }\end{array}$ & $\begin{array}{l}\text { User defined, 1 } \\
\text { minute or } \\
\text { smaller }\end{array}$ & $\begin{array}{l}\text { Site to } \\
\text { watershed, } \\
\text { subcatchments } \\
\text { intended to be } \\
\text { large }\end{array}$ \\
\hline SUSTAIN & $\begin{array}{l}\text { Stand-alone } \\
\text { program }\end{array}$ & $\begin{array}{l}\text { Placement and } \\
\text { sizing of } \\
\text { stormwater } \\
\text { BMPs to meet } \\
\text { cost, water } \\
\text { volume, and } \\
\text { water quality } \\
\text { goals }\end{array}$ & $\begin{array}{l}\text { High } \\
\text { (substantial } \\
\text { calibration) }\end{array}$ & $\begin{array}{l}\text { Land use, watershed, } \\
\text { precipitation, } \\
\text { elevation, BMP } \\
\text { configuration, } \\
\text { routing network } \\
\text { (extensive } \\
\text { formatting required) }\end{array}$ & $\begin{array}{l}\text { Average and range of } \\
\text { flow volumes, flow } \\
\text { reductions, sediment } \\
\text { and pollutant loads in } \\
\text { one assessment point } \\
\text { in each subcatchment }\end{array}$ & $\begin{array}{l}\text { Hourly or sub- } \\
\text { hourly, as small } \\
\text { as 1-minute } \\
\text { increments } \\
\text { depending on } \\
\text { modules in use }\end{array}$ & $\begin{array}{l}\text { Site to watershed } \\
\text { Yes }\end{array}$ \\
\hline
\end{tabular}





\section{Table 2: Default values for global variables.}

\begin{tabular}{ll} 
Variable & Value \\
\hline Evaporation & $3.5625 \mathrm{~mm} /$ day \\
Evapotranspiration & $1.66 \mathrm{~mm}$ /day \\
Manhole Volume & $2.18 \mathrm{~m}^{3}$ \\
Manhole Sump & $25 \%$ of manhole volume \\
Sewer Intake Rate & $0.51 \mathrm{~m}^{3}$ per 30 -seconds time step \\
Stormwater Treatment Rate & $9.37 \mathrm{~m}^{3}$ per 30 -second time step \\
Maximum Sewer System & $141,560 \mathrm{~m}^{3}$ \\
Capacity &
\end{tabular}


Table 3: Soil and Surface Flow Variables by Cover Type or Green Infrastructure. Sources: California Department of Transportation, 2009 (十);Dallas, City of, (1993) ( $\triangle$ ); Gonzalez-Meler et al., 2013 (४); Hunt, 2006 (匹); Morrow \& Sharpe, 2009 (*); Oram, N.d (•);US Department of Agriculture, 1986 ( $\nabla)$

\begin{tabular}{|c|c|c|c|}
\hline Soil Variable & $\begin{array}{l}\text { Green } \\
\text { Infrastructure } \\
\text { (loamy sand } \\
\text { soil) } \\
\end{array}$ & Impervious cover & $\begin{array}{l}\text { Permeable cover } \\
\text { (silty clay loam } \\
\text { soil) }\end{array}$ \\
\hline Surface storage capacity & $200 \mathrm{~mm}$ & $0 \mathrm{~mm}$ & $0 \mathrm{~mm}$ \\
\hline Engineered soil depthø & $1,019 \mathrm{~mm}$ & $0 \mathrm{~mm}$ & $0 \mathrm{~mm}$ \\
\hline Depth to water table* & $1,019 \mathrm{~mm}$ & $1,219 \mathrm{~mm}$ & $1,219 \mathrm{~mm}$ \\
\hline Capillary suction• & $61.3 \mathrm{~mm}$ & $\mathrm{n} / \mathrm{a}$ & $273 \mathrm{~mm}$ \\
\hline Initial moisture deficit• & 0.312 & $\mathrm{n} / \mathrm{a}$ & 0.105 \\
\hline Saturated hydraulic conductivity & $59.8 \mathrm{~mm} / \mathrm{hr}$ & $\mathrm{n} / \mathrm{a}$ & $2 \mathrm{~mm} / \mathrm{hr}$ \\
\hline Roughness coefficient & $.24+$ & $.0175 \Delta$ & $.15 \nabla$ \\
\hline
\end{tabular}


Table 4: Parameter settings for simulations (Note: Scenario settings are shown in bold).

\begin{tabular}{|c|c|}
\hline Variable & Value \\
\hline Outlet & on \\
\hline Sewers & on \\
\hline Slope of landscape & $0.25 \%$ \\
\hline Curbs & on \\
\hline Curb height & $127 \mathrm{~mm}$ \\
\hline Intersection berm height & $101.6 \mathrm{~mm}$ \\
\hline Percent impervious & $50 \%$ \\
\hline Allow CSOs? & No \\
\hline Sewer spacing & Every fifth road cell \\
\hline Cell dimensions & $10 \mathrm{~m}$ by $10 \mathrm{~m}$ \\
\hline Road width & $10 \mathrm{~m}(1$ cell $)$ \\
\hline Block dimensions & $200 \mathrm{~m}$ by $100 \mathrm{~m}$ (20 by 10 cells) \\
\hline Landscape dimensions & 2 km by 2 km (200 by 200 cells) \\
\hline Storm duration & 24 hours \\
\hline Storm intensity & $\begin{array}{l}\text { 5- and 100-year (total precipitation of } \\
95.76 \mathrm{~mm} \text { and } 182.88 \mathrm{~mm} \text {, respectively) }\end{array}$ \\
\hline Percent green infrastructure & $0-\mathbf{5 0 \%}$ \\
\hline \multirow[t]{4}{*}{ Green infrastructure placement } & Baseline: Sorted Random \\
\hline & Upstream - Downstream \\
\hline & Adjacent to roads - Away from roads \\
\hline & Hybrid \\
\hline
\end{tabular}

